\title{
Foreign Bank Participation and Crises in Developing Countries*
}

\author{
Robert Cull \\ Finance and Private Sector Development Research Group \\ The World Bank \\ María Soledad Martínez Pería \\ Finance and Private Sector Development Research Group \\ The World Bank
}

\begin{abstract}
This paper describes the recent trends in foreign bank ownership in developing countries, summarizes the existing evidence on the causes and implications of foreign bank presence, and re-examines the link between banking crises and foreign bank participation. Using data on the share of banking sector assets held by foreign banks in over 100 developing countries during 1995-2002, the results show that countries that experienced a banking crisis tended to have higher levels of foreign bank participation than those that did not. Furthermore, panel regressions indicate that foreign participation increased as a result of crises rather than prior to them. However, post-crisis increases in foreign participation did not coincide with increased credit to the private sector, perhaps because in many cases foreign banks acquired distressed banks.

Keywords: foreign banks, crises

JEL classification: F23, F36, G21
\end{abstract}

World Bank Policy Research Working Paper 4128, February 2007

The Policy Research Working Paper Series disseminates the findings of work in progress to encourage the exchange of ideas about development issues. An objective of the series is to get the findings out quickly, even if the presentations are less than fully polished. The papers carry the names of the authors and should be cited accordingly. The findings, interpretations, and conclusions expressed in this paper are entirely those of the authors. They do not necessarily represent the view of the World Bank, its Executive Directors, or the countries they represent. Policy Research Working Papers are available online at http://econ.worldbank.org.

\footnotetext{
${ }^{*}$ We are grateful to Soledad Lopez for outstanding research assistance. Contact information: Robert Cull, Senior Economist, Finance and Private Sector Development Research Group, World Bank, 1818 H Street, N.W., MSN MC3-300. Email: rcull@worldbank.org. Maria Soledad Martinez Peria, Senior Economist, Finance and Private Sector Development Research Group, World Bank, 1818 H Street, N.W., MSN MC 3-300. Email: mmartinezperia@worldbank.org.
} 


\section{Introduction}

Since the mid 1990s, due to a growing trend across countries towards globalization and financial integration, banking sectors in many developing countries have experienced some important transformations. Key among them has been a rapid increase in the degree of foreign bank participation. Between 1995 and 2002, the average share of banking sector assets held by foreign banks in 104 developing countries rose from 18 percent to 33 percent. ${ }^{1}$

Many studies have examined the causes and implications of foreign bank participation. ${ }^{2}$ The contribution of this paper is to describe the recent trends in foreign bank ownership in developing countries, summarize the existing evidence on the causes and implications of foreign bank presence and re-examine the link between banking crises and foreign bank participation. Using data on the share of banking sector assets owned by foreign banks in over 100 developing countries, we document a strong rise in foreign bank participation in two regions of the world: Eastern Europe and Central Asia and Latin America. Foreign bank presence has increased in Africa as well, but at a generally slower pace than in the other two regions. By contrast, foreign bank participation has remained stagnant or even declined in East and South Asia and in the Middle East and North Africa.

Our empirical analysis shows that countries that experienced a banking crisis from 1995 to 2002 tended to have higher levels of foreign bank participation than those that did not. Furthermore, panel regressions indicate that foreign bank participation increased as a result of crises rather than prior to them. However, post-crisis increases in foreign bank participation did not coincide with increased credit to the private sector. We speculate that this is due to the fact that in most countries foreign entrants acquired distressed banks with a high share of loans that needed to be written off. By contrast, in countries where the level of foreign bank participation was relatively high and stable, private credit levels were significantly higher than in other countries before, during, and after crises.

The paper is organized as follows. Section 2 examines the recent trends in foreign bank participation among developing countries. Section 3 reviews the existing literature on the causes

\footnotetext{
${ }^{1}$ These data come from Micco, Panizza, and Yañez (2006). We exclude developed countries and off-shore centers. If we take the average over the 72 countries for which information exists for each year between 1995 and 2002 , the average participation in developing countries is not substantially different. It rose from 17 to 31 percent.

${ }^{2}$ See the literature review in Section 3.
} 
and implications of foreign bank participation. Section 4 examines the relationship between crises and foreign bank participation in developing countries and Section 5 concludes.

\section{Trends in foreign bank participation}

Statistics on the average share of banking assets held by foreign banks in developing countries over the last decade disguise important regional differences, as well as differences within each region. This section describes levels and trends in foreign bank participation across regions and also discusses the degree to which recent regional changes in foreign bank participation are common to most countries in the region or are driven by only a few exceptions.

As shown in Figure 1, between 1995 and 2002 foreign bank participation increased primarily in Eastern Europe and Central Asia, Latin America, and Sub-Saharan Africa. ${ }^{3}$ By 2002 , close to 40 percent of assets in all three regions were in the hands of foreign banks. On the other hand, in Asia and in the Middle East and Northern Africa, foreign bank participation remained low - close to 10 percent of banking sector assets - and stagnant throughout the period.

Even among the three regions where the share of assets held by foreign banks has been rising there are some differences both in the levels of foreign bank presence and in the speed with which it has increased in recent years. For example, whereas the average level of foreign bank participation during 1995-2002 was highest in Sub-Saharan Africa, both the absolute and relative increases in the share of assets held by foreign banks have been most significant in Eastern Europe and Central Asia and in Latin America. The share of assets held by foreign banks in Sub-Saharan Africa rose by 9 percentage points from 30 percent in 1995 to 39 percent in 2002. This represents a 1.3 times increase. In Eastern Europe and Central Asia the share of assets held by foreign banks roughly tripled from almost 13 percent in 1995 to 39 percent in 2002. In Latin America, foreign bank participation nearly doubled, going from 19 percent to 37 percent over this period.

While in Africa, many of the foreign banks have been operating since colonial times, entry in Eastern Europe and Latin America has been more recent. Most of the entry of foreign banks in Eastern Europe and Central Asia has resulted from the privatization of state-owned

\footnotetext{
${ }^{3}$ Because here we compare averages across regions, to avoid that statistics are affected by changes in the sample composition over time, we focus only on countries in each region for which we have data on foreign bank participation for every year between 1995 and 2002. This means that we calculate regional averages over a sample of 72 countries instead of 104, which is the total number of developing countries for which we have data from Micco et al. (2006).
} 
banks following the fall of communism in the region. The largest five foreign banks with operations in Eastern Europe and Central Asia are KBC Bank (Belgium), Erste Bank (Austria), HVB Group (Austria), Société Générale (France) and Unicredito Italiano (Italy). There are regional specializations of some foreign banks: large Scandinavian banks like Swedbank and Skandinavska Enskilda have the markets of the Baltic States, and Greek banks such National Bank of Greece, Piraeus Bank, Alpha Bank, and Emporiki Bank of Greece are present in the Balkan countries. At the same time, Austrian banks - Erste Bank, HVB Group and Raiffeisen control large shares of banking assets in most Eastern European and Central Asian countries, with the exception of the Baltic States. In Latin America, entry has been driven by foreign bank acquisitions of domestic banks. In particular, two Spanish banks - Banco Santander Central Hispano and Banco Bilbao Viscaya Argentaria (BBVA) - have been particularly aggressive in acquiring banks in the region. ${ }^{4}$ However, other non-Spanish banks such as Citibank from the U.S. and HSBC from the U.K. also have an important presence in the region.

East Asia had the lowest levels of foreign bank participation throughout the period 19952002 and also exhibited the smallest increase. The share of assets held by foreign banks was close to 7 percent throughout the entire period. In terms of levels of foreign bank presence, South Asia follows East Asia as the region with the lowest levels of foreign bank participation. In South Asia, the share of assets held by foreign banks was almost 9 percent in 1995 and rose to 12 percent in 2000 only to drop to 10 percent by 2002. Finally, foreign bank participation in Middle East and North Africa was close to 12 percent in 1995 and rose only to almost 13 percent by 2002..$^{5}$

Table 1 presents detailed information on the share of assets held by foreign banks in each of 104 developing countries. This allows us to examine more closely whether the regional trends described above were driven by most or only some of the countries in each region. In SubSaharan Africa, the increase in foreign bank participation was a fairly widespread phenomenon. Foreign bank participation increased in 22 out of the 30 African countries for which we have data on foreign bank participation. In absolute terms (i.e., percentage point changes in the share of assets held by foreign banks), the increase in foreign bank participation was most significant

\footnotetext{
${ }^{4}$ Banco Santander has operations in 15 Latin American and Caribbean countries, while BBVA is present in 11 countries in the region.

${ }^{5}$ Algeria, where foreign bank participation averaged 62 percent throughout the period, is a clear outlier in the region.
} 
in Mozambique and Cote d'Ivoire, where the share of assets held by foreign banks increased by over 40 percentage points. In Mozambique, foreign bank participation increased from close to 22 percent in 1996 to over 72 percent in 2002. In Cote d'Ivoire, foreign bank presence rose from 20 percent in 1995 to 62 percent in 2002. In relative terms (i.e., with respect to their initial levels of foreign bank presence), both Sierra Leone and South Africa experienced significant increases in the share of foreign bank participation. In Sierra Leone, the share of assets held by foreign banks rose from 0 to over 29 percent and in South Africa it increased from 0.3 to almost 11 percent. On the other hand, the share of assets held by foreign banks declined in 6 countries in the region, namely: Burkina Faso, Burundi, Cameroon, Niger, Senegal, and Zimbabwe. In Ethiopia and Seychelles, foreign participation did not change.

In Eastern Europe and Central Asia, the increase in foreign bank participation observed over the last decade was also quite pervasive. Out of 25 countries in the region for which we have data on foreign bank participation, the share of assets held by foreign banks increased in 22 of them. The increase was particularly spectacular in Lithuania and the Slovak Republic, where the share of assets controlled by foreign banks rose by over 70 percentage points. In Lithuania, foreign bank participation rose from close to 19 percent in 1995 to over 90 percent in 2002. The Slovak Republic witnessed an increase in the share of assets held by foreign banks from 9 to almost 82 percent. Relative to the beginning levels of foreign bank presence, Romania also experienced a significant increase in foreign bank participation. In this country, the share of bank assets held by foreign banks rose from almost 0 to 26 percent in 2002. On the other hand, in countries such as Azerbaijan, Serbia, Turkey, and Uzbekistan foreign bank participation remained insignificant ( 0 or close to it) and not changing over the period 1995-2002.

In Latin America, foreign bank participation increased in 17 out of 23 countries in our sample. The increase in foreign bank participation was especially noteworthy in Mexico and Uruguay. In Mexico, the share of assets held by foreign banks increased from 2.31 percent in 1995 to 61.9 in 2002. In Uruguay, foreign bank participation rose from 24 percent to almost 95 percent in 2002. Ecuador is the only country in the region where foreign bank participation dropped significantly. Between 1997 and 2000 the share of assets held by foreign banks collapsed from close to 26 percent to almost 0. Countries such as Bolivia, Panama, and Trinidad and Tobago also experienced a decline in foreign bank participation between 1995 and 2002, but 
the drop was much smaller by comparison. In Panama and Bolivia, by 2002, the share of assets held by foreign banks still exceeded 40 and 50 percent, respectively.

In the Middle East and North Africa region, the share of assets held by foreign banks increased significantly only in the case of Oman, where foreign bank participation rose from 0 to 8 percent of banking sector assets. In Egypt and Tunisia, foreign bank presence rose by less than 5 percentage points. In the case of Egypt, the share of assets held by foreign banks rose from 4 to 7 percent and in Tunisia it increased from 11 to 15 percent. In Lebanon, Morocco, and Yemen foreign bank participation declined over the period 1995-2002. In Yemen, the share of assets held by foreign banks dropped from almost 7 to 2 percent. Morocco experienced a drop in foreign bank participation from 19 to 16 percent, while in Lebanon the share of assets held by foreign banks dropped from 30 to 28 percent. In Iran and Lybia the share of assets held by foreign banks remained at zero throughout the period. Finally, Algeria is a clear outlier in the region where foreign bank participation averaged 62 percent throughout the period.

Nepal and Pakistan were the only two countries in South Asia where foreign bank participation increased between 1995 and 2002. In Nepal, the share of assets held by foreign banks rose from 38.8 to 45.4 percent. In Pakistan, the increase was smaller. Foreign bank participation rose from 1.4 to almost 6 percent. In both India and Sri Lanka, the share of assets held by foreign banks dropped between 1995 and 2002. In the case of India, foreign bank participation rose from 0.9 in 1995 to 1.7 in 2000, only to fall to 0.6 percent in 2002. In Sri Lanka, foreign bank presence dropped from 2-3 percent during 1995-2001 to less than 0.3 percent by 2002. In the case of Bangladesh, there was no foreign bank presence throughout the period 1995-2002.

With the exception of Mongolia - where the share of assets held by foreign banks rose from 0 to 45 - and to a lesser degree Korea - where foreign bank participation increased from 2 to 9 percent - in most other countries in East Asia, the share of assets held by foreign banks remained constant or declined over the period 1995-2002. In the case of Indonesia, the share of foreign bank assets averaged close to 4 percent throughout the period 1995-2002. Foreign bank participation stood at 23-26 percent in Malaysia, 8-9 percent in the Philippines and 7-10 percent in Thailand. Finally, China remained largely closed to foreign banks between 1995 and 2002.

Overall, the data on foreign bank participation suggests that regional trends in foreign bank presence were common to most countries within each region, with the share of assets held 
by foreign banks rising in Eastern Europe and Central Asia, Latin America and Sub-Saharan Africa, and remaining constant or declining in East Asia, South Asia, North Africa and the Middle East.

\section{Survey of the causes and implications of foreign bank participation}

This section reviews the literature on the causes and implications of foreign bank participation in developing countries. Regarding the impact of foreign bank participation, we summarize the existing evidence on the effects of foreign bank presence on efficiency, bank competition, stability, and access to credit.

\subsection{What drives foreign bank participation?}

To date the existing literature on foreign bank entry discusses the following factors as potential drivers of foreign bank participation: (a) banks' desire to service their customers abroad - the so called "follow the clients" motive, (b) host-specific factors including market opportunities and regulatory barriers and (c) economic and cultural ties and institutional and regulatory similarities between home and host countries. ${ }^{6}$

An early strand of the literature on the decision by foreign banks to operate overseas focused on the experience of developed countries (especially the U.S.) with foreign bank entry and bank internationalization during the 1970s and 1980s (see Goldberg and Saunders, 1980, 1981a, b; Ball and Tschoegl, 1982, Nigh et al., 1986; Cho et al., 1987; Hultman and McGee, 1989; Goldberg and Johnson, 1990; Goldberg and Grosse, 1994, Fisher and Molyneaux, 1996). A majority of these studies find support for the hypothesis that banks go abroad to service their domestic clients with overseas operations. Most studies test this hypothesis by looking at the significance of variables such as the level of foreign direct investment by non-financial firms into the host country. While the evidence on the "follow the clients" motivation seems solid when it comes to developed countries, there is less consensus as to its importance in driving foreign bank participation in developing countries. Most of the early studies that explored this hypothesis included few developing host countries in their sample. Furthermore, in one case where separate estimations where conducted for the subsample of developing countries (see Miller and Parkhe,

\footnotetext{
${ }^{6}$ These factors are also highlighted by Clarke et al. (2003). The main difference is that we cite evidence based primarily on foreign entry into developing countries. They primarily refer to literature on foreign bank activities in the U.S. and other developed countries.
} 
1998), the authors could not find a significant link between foreign direct investment by nonfinancial firms and foreign bank activities in those countries.

Relative to the "follow the clients" motivation, there is consistent evidence for the importance of local market opportunities in driving foreign bank participation. Using data on the location choices of 143 banks with at least one shareholding abroad across 28 countries (including 6 developing countries: Czech Republic, Hungary, Korea, Poland and Turkey), Focarelli and Pozzolo (2001) find greater foreign bank entry in countries where the expected rate of economic growth is higher. Analyzing 2,300 international bank mergers that took place between 1978 and 2000 in developed and developing countries, Buch and DeLong (2004) find that foreign banks tend to go to larger yet less developed economies, where there is the prospect for economies of scale and future growth opportunities. Similarly, looking into the foreign direct investments of German banks across 190 countries during the second half of the 1990s, Buch and Lipponer (2004) find that, other things equal, German banks are attracted to larger markets (in terms of GDP).

Many studies have also documented the importance of regulatory barriers as obstacles to foreign bank entry. In their study of international bank mergers, Buch and De Long (2004) find that banks operating in more regulated environments are less likely to be the targets of international bank mergers. Similarly, Focarelli and Pozzolo (2001) find that foreign banks prefer to invest in countries with fewer regulatory restrictions on bank activities. Looking at the foreign asset holdings between 1983 and 1999 of international banks that report data to the Bank for International Settlements, Buch (2003) finds that regulations are important in influencing the international asset choice of banks. Finally, focusing on the specific case of German banks' foreign assets holdings across countries, Buch and Lipponer (2004) find that if countries impose controls on cross-border financial credits, they receive less foreign direct investment from German banks and banks also perform fewer cross-border financial services in those countries.

The evidence on the importance of geographical proximity and economic and cultural similarities in driving foreign bank participation is quite overwhelming. Studies such as Buch and De Long (2004), Buch (2003), Galindo, Micco, and Serra (2003), Buch and Lipponer (2004), Claessens and Van Horen (2006) have shown that bilateral distance, sharing a border, speaking a common language, having common colonial ties are all factors that influence foreign bank entry. There is also some evidence that similarities in the legal, regulatory and institutional 
environment matter, but there is less agreement as to whether absolute differences or differences vis-à-vis competitors are important. Galindo, Micco, and Serra (2003) argue that absolute legal, regulatory and institutional differences across countries can increase entry costs and reduce the participation of banks in foreign countries. Using bilateral foreign banking data for 176 countries, the authors find results that support their hypotheses. In other words, they find that foreign bank penetration is higher between countries that have similar legal origins, banking regulations, and institutional set ups. On the other hand, Claessens and Van Horen (2006) argue that what is important in driving foreign bank participation is not the difference between the institutional environment in the host and source country, but rather the difference taking into account the institutional quality of the competitors from other source countries. Using data for most banks in all developing countries, the authors find that absolute levels of institutional differences between the host and source countries do not matter once they control for the relative advantage the source country has compared to its competitors from other countries operating in the same host.

To summarize, there is substantial evidence that factors such as market opportunities, regulatory barriers in the host countries along with economic, cultural and institutional similarities between home and host economies influence the decision of banks to operate overseas. Contrary to the wealth of evidence on these factors, the role that crises can play in bringing about foreign bank participation has only been discussed anecdotally. For example, in discussing the rise in foreign bank participation in Argentina, Brazil and Mexico, Peek and Rosengren (2000) mention the Tequila Crisis in Mexico and Argentina and the 1999 Brazilian crises as catalytic events. Moreno and Villar (2006) also point to the experience of Mexico in stating that foreign bank entry might be stimulated by the need for countries to recapitalize their banking systems in the aftermath of crises. Similarly, Tschoegl (2003) discusses the importance of crises in bringing about the subsequent entry of foreign banks in emerging markets focusing on 12 countries. Yet, solid empirical evidence on the role of crises is lacking. Section 4 will attempt to fill the gap in the literature by exploring the statistical association between crises and foreign bank participation. We turn next to the implications of foreign bank participation for the degree of competition, efficiency, stability and access to credit in the host countries. 


\subsection{What is the impact of foreign bank participation in developing countries?}

\section{(i) Competition \& Efficiency}

The promises of efficiency improvements and greater competition in the banking sector are perhaps the main arguments brought forth by proponents of foreign bank entry. As detailed below, with the exception of research that focuses on Latin America where the evidence is mixed, existing studies on the impact of foreign bank participation on efficiency and competition largely support the claim that foreign banks operating in developing countries are more efficient than domestic banks (i.e., have lower overhead costs), charge lower spreads, and help promote bank competition by pressuring other banks to lower their costs and their spreads.

Claessens, Demirguc-Kunt and Huizinga (2001), Claessens and Lee (2003), and Claessens and Laeven (2003) offer cross-country evidence on the benefits of foreign bank participation in terms of efficiency gains and greater competition. Using data for 80 countries from 1995 to 1998, Claessens, Demirguc-Kunt and Huizinga (2001) find that foreign bank participation is associated with a reduction in profitability, non-interest income and overhead expenses of domestic banks - results which they interpret as indications of greater efficiency and competition due to foreign bank participation. In a follow-up paper, Claessens and Lee (2003) focus on financial systems in 58 low-income countries. They find that the increased presence of foreign banks benefited the local banking sector by reducing financial intermediation costs making the banking system more efficient and robust. Following the Panzar and Rose (1987) methodology to obtain a parameter that quantifies the degree of competition in the banking sector in 50 countries between 1994 and 2001, Claessens and Laeven (2003) find that systems with greater foreign bank entry and with fewer activity and entry restrictions are more competitive.

A variety of country and regional case studies complement the cross-country literature on the impact of foreign bank participation on efficiency and competition. Using bank accounting data from Philippines for 1990-98, Unite and Sullivan (2002) investigate how foreign bank entry and increased foreign ownership of banks in that country affected bank efficiency and competition. The authors find that greater foreign bank entry reduced the interest rates and operating expenses of domestic banks, but not their profitability. They conclude that foreign competition forced domestic banks to be more efficient. Denizer (2000) studies the impact of 
foreign bank participation in Turkey between 1980 and 1997. The study shows that foreign bank entry had a positive impact on competition in the sector as witnessed by the decline in profits and overhead costs. Looking at the performance of 219 banks, between 1995-2001, from a sample of ten countries in Central and Eastern Europe (Bulgaria, Croatia, Czech Republic, Estonia, Hungary, Latvia, Lithuania, Poland, Slovenia, and Slovakia), Uiboupin (2004) offers evidence consistent with the notion that foreign bank entry increased competition in those countries. In particular, the study finds that foreign entry is associated with lower profits, non-interest income, and loan interest rates.

In the case of Latin America, however, the evidence on the impact of foreign bank entry on bank competition and efficiency is mixed. Studies such as Barajas, Steiner, and Salazar (2000) and Martinez Peria and Mody (2004) offer evidence in favor of the hypothesis that foreign bank participation improves efficiency and competition. On the other hand, others such as Haber and Musacchio (2005), Schulz (2006) and Levy-Yeyati and Micco (2007) provide evidence to the contrary.

Barajas, Steiner, and Salazar (2000) study the competitive effect of foreign entry in Colombia, using panel estimation and controlling for other aspects of financial liberalization (including the number and relative size of new domestic entrants and overall increases in capital flows). They find that foreign entry improved the efficiency of the domestic banking system by reducing nonfinancial costs. Similarly, Martinez Peria and Mody (2004) offer evidence consistent with the notion that foreign bank participation had positive implications for the Latin American region enhancing efficiency and competition. Focusing on Argentina, Chile, Colombia, and Mexico, Martinez Peria and Mody (2004) find that foreign bank participation did not affect spreads directly, but caused a drop in administrative costs. This result is consistent with the notion that foreign participation improved efficiency and fostered competition.

In the case of Mexico, foreign bank participation has not been found to increase competition and efficiency. Haber and Musacchio (2005) show that the entry of foreign banks led, instead, to a retrenchment in lending and no improvements in efficiency and competition. They argue that this is related to the fact that Mexico had an extremely concentrated banking system both before and after foreign bank entry. Focusing also on the case of Mexico, Schulz (2006) shows that foreign bank entry from 1997 to 2004 had no effect on administrative costs and employment levels. He too argues that this lack of impact on the overall efficiency of the 
sector can be explained as a result of limited competitive pressures. Finally, using data for eight countries in the region - Argentina, Brazil, Chile, Colombia, Costa Rica, El Salvador, Mexico and Peru - Levy Yeyati and Micco (2007) find that foreign bank penetration weakened competition in the region as measured by the $\mathrm{H}$ statistic proposed in Panzar and Rose (1987).

All in all the evidence on competition and efficiency suggests that foreign bank entry can bring potential gains in this area except in environments which limit competitive forces such as when bank concentration is high, bank activities are restricted, and bank entry and exit is difficult.

\section{(ii) Stability}

The rise in importance of foreign banks in developing countries has led to an intense debate on the pros and cons of foreign bank participation in terms of its impact on stability. Those opposed to foreign bank participation argue that because foreign banks have weaker ties to developing nations and have more alternative business opportunities than domestic banks, they are more likely to be fickle lenders. Furthermore, there is also the potential that they could import shocks from their home countries. On the other hand, in favor of greater stability is the notion that foreign banks are typically well diversified institutions, with access to many sources of liquidity that will be less affected by shocks.

Though some studies have found that foreign banks can respond to shocks from their home countries (see Goldberg, 2002; Martinez Peria, Powell and Vladkova-Hollar, 2005), a larger number of studies have found that they tend to be more stable lenders than domestic banks, in particular during periods of crisis in developing countries. Looking at the behavior of banks in Argentina and Mexico during the 1994-95 Tequila crisis, Goldberg, Dages and Kinney (2000) find that foreign banks generally had higher loan growth rates than their domesticallyowned counterparts, with lower volatility of lending contributing to lower overall volatility of credit. Peek and Rosengren (2000) reach a similar conclusion after examining direct and crossborder foreign bank lending in Argentina, Brazil, and Mexico during 1994-1999. Using bank level data for the late 1990s for Argentina, Chile and Colombia, Crystal, Dages, and Goldberg (2001) show that foreign banks on average exhibited higher loan growth rates than domestic banks. Examining the behavior of foreign and domestic banks in Malaysia during the 1997-98 Asian crisis, Detragiache and Gupta (2006) find no evidence that foreign banks abandoned the 
local market during the crisis. Finally, De Haas and van Lelyveld (2006) examine how foreign and domestic banks in ten Central and Eastern Europe (CEE) reacted to business cycle conditions and host country banking crises from 1993 to 2000. ${ }^{7}$ Their results show that while during crises domestic banks contracted their credit, foreign banks maintained their credit supply.

Overall, the evidence available so far suggests that foreign banks can have a stabilizing influence on credit markets in developing countries, at least where financial sector depth is concerned. Next we turn to the impact of foreign bank participation on financial sector breadth or reach.

\section{(iii) Access to credit}

The extent to which foreign banks contribute to greater access to credit, in particular for small firms, in developing countries is perhaps the most controversial aspect of the process of foreign bank participation. Those opposing this process ague that foreign banks are likely to "cherry pick" the most profitable and transparent customers, reducing financing to some market segments, like small businesses. On the other hand, those in favor of foreign bank entry point to the fact that foreign banks have access to a larger pool of loanable funds that can help them sustain higher levels of lending. Also, proponents of foreign bank participation argue that even if foreign banks focus on the most transparent firms, this process can enhance access to credit by smaller firms by forcing domestic banks to move down the market. The existing empirical evidence on the impact of foreign bank participation on access to credit is to date mixed.

Studies such as Berger, et al. (2001), Detragiache, Gupta, and Tressel (2005), and Mian (2006) present evidence that suggests that foreign banks limit access and serve only the largest and most transparent firms in an economy. Using data for 61,295 firms with 195,695 loans from 115 different banks in Argentina as of the end of 1998, Berger et al. (2001) find that smaller and more opaque firms are less likely to obtain loans from large or foreign-owned banks. Detragiache, Gupta and Tressel (2005) develop a model that shows that when foreign banks have a more efficient technology to monitor high-end customers than domestic banks, foreign bank participation may lead to lower aggregate credit, higher operating costs, and lower welfare. Using data for 89 low income and lower middle income countries, they find that a larger foreign

\footnotetext{
${ }^{7}$ Croatia, Czech Republic, Estonia, Hungary, Latvia, Lithuania, Poland, Romania, Slovak Republic and Slovenia
} 
bank presence is associated with shallower credit markets and slower credit growth, as in the "cream-skimming" equilibrium in their model. Focusing specifically on the case of Pakistan, using a panel of 80,000 loans over 7 years, Mian (2006) finds that foreign banks in Pakistan shy away from lending to "soft information" firms such as those that are small, located in rural areas, not affiliated with business groups, or seeking first-time loans and long-term relational financing. Also, he finds that foreign banks are less likely to bilaterally renegotiate and are less successful at recovering loans. Finally, Mian shows that measures of geographical or cultural distance between the firm in the host country and the home country go a long way in explaining the differences found in the lending, recovery, and renegotiation patterns of foreign and domestic banks.

In contrast to the studies discussed above, research by Clarke, Cull, Martinez Peria and Sanchez (2005), Giannetti and Ongena (2005), and Clarke, Cull and Martinez Peria (2006) offers some evidence that foreign bank participation may not always be pernicious for access to credit in host developing countries. Using bank-level data for four Latin American countries (Argentina, Chile, Colombia and Peru) during the mid-1990s, Clarke, Cull, Martinez Peria and Sanchez (2005) investigate whether bank origin affects the share and growth of lending to small businesses. While they find that on average foreign banks seem to lend less to small businesses, they also uncover significant differences between small and large foreign banks. In fact, at least in these countries, large foreign banks often surpass large domestic banks in their share and growth of lending to small businesses.

Instead of using bank level data, Giannetti and Ongena (2005) and Clarke, Cull and Martinez Peria (2006) offer evidence on the effects of foreign bank participation on access to credit using firm-level data. Giannetti and Ongena (2005) employ a large panel of almost 60,000 firm-year observations on listed and unlisted companies in Eastern Europe to investigate the impact of foreign bank lending on firm growth and financing. They find that foreign lending stimulates growth in firm sales, assets, and leverage. Though the effect is smaller for small firms, they conclude that large firms benefit more from foreign bank presence, but even small companies profit from foreign bank entry. Combining responses from a survey of over 3,000 firms operating in 35 developing countries with data on the degree of foreign bank presence across these countries, Clarke et al. (2006) find that all enterprises, including small and medium- 
sized ones, report facing lower financing obstacles in countries having higher levels of foreign bank presence.

In summary, the evidence on the implications of foreign bank participation for access to credit suggests that foreign banks are generally less inclined to lend to small and opaque borrowers relative to domestic banks. Nevertheless, there is also evidence that their presence can have overall positive effects on access to credit, even if foreign banks themselves are not lending to small firms.

\section{Foreign bank participation and crises}

This section studies the link between foreign bank presence and crises. We begin by presenting data on the prevalence of banking crises and on the post-crisis levels of foreign participation across regions. Then, we use cross-country regressions to test whether countries that had crises also had higher levels of foreign participation in banking. Next, we present panel estimations with country-level fixed effects that allow us to control for unobserved country characteristics and enable us to pinpoint better the timing of the increases in foreign bank presence. In this way, we can assess whether foreign participation occurred in response to banking crises. Finally, we conduct panel regressions that test whether higher levels of foreign participation coincided with increased provision of credit to the private sector.

\subsection{Crises and Foreign Bank Participation: General Patterns}

Banking crises are a fact of life in developing economies. Since the mid-1990s, 77 crises episodes have taken place in 72 developing countries. Table 2 shows crisis episodes as identified by Caprio and Klingebiel (2003). The table illustrates that banking crises have occurred in at least one country in each region of the developing world.

Crises represent enormous challenges to policy-makers in developing countries. As shown in Table 2, the costs of dealing with crises (e.g., paying for deposit losses, recapitalizing banks, and building banking systems that are more resilient to shocks) can be very large. Moreover, most crises have macroeconomic roots and take place in environments where governments have already difficult fiscal situations. Table 3 shows the average budget deficit to GDP in each region three years before and three years after crises. This table illustrates how even 
before the start of crises, governments in most regions were already running budget deficits, a fact that should hamper their ability to deal with the cost of these episodes subsequently.

Yet, crises also represent opportunities for developing countries since they prompt governments to think differently and creatively about the problems they confront. In many developing countries, crises have encouraged governments to deregulate their banking sectors and to allow the entry of foreign banks. Table 4 shows average values of a measure of banking sector restrictions across countries that had crises between 1995 and 2002 and those that did not. ${ }^{8}$ The index takes values from 1 to 5 with higher values representing greater restrictions. With the exception of Asia, countries that have experienced crises tended to be more open subsequently than countries that never experienced a crisis.

Though many studies have discussed the catalytic role that crises can play in promoting foreign bank participation in developing countries, few have offered systematic evidence to this effect. We begin by plotting the share of foreign bank assets in each region in a five year period following crises occurring between 1995 and 2002. The most reliable time series on foreign bank assets, which was constructed by Micco et al. (2006) from Bankscope data, are only available for those years. Because crises did not occur in the same years in all countries, we date as " $\mathrm{t}$ " the first year of the crisis for each country and we take the average share of foreign bank participation at that point in time for each region. We compute regional averages for each year after the crisis within a five year window in the same manner.

We see from Figure 2 that crises in Africa, Latin America, and in particular, in Eastern Europe and Central Asia have been followed by an increase in foreign bank participation. On average, the share of assets held by foreign banks in Eastern Europe and Central Asia increased from 10 to 32 percent within the five year period following crises. In Africa, foreign bank participation increased from an average of 32 percent to almost 45 percent five years after crises. In Latin America, the increase was smaller, with foreign bank participation increasing from 28 to 32 percent.

\footnotetext{
${ }^{8}$ Among the restrictions that the Heritage Foundation considers in constructing this index are: the ease with which foreign banks can open branches and subsidiaries, government interference in the allocation of credit including government ownership of banks, the ability of private banks to operate without government regulation such as deposit insurance, and the ability of banks to provide a wide range of financial services (including real estate and securities transactions, and insurance).
} 


\subsection{Crises and Foreign Participation: Cross-Country Regressions}

To further assess the role that crises play in promoting foreign bank participation we estimate equation (1), in which we regress the change in foreign bank participation between 1995 and 2002 on a dummy for whether countries had crises over this period along with a number of controls:

$$
\begin{aligned}
& \Delta \text { Foreign Bank Participation }_{\mathrm{i}}=\alpha+\beta_{1} \text { Crisis }_{\mathrm{i}}+\beta_{2}{ }^{\prime} \text { Macro }_{\mathrm{i}}+\beta_{3} \text { Banking Index }_{\mathrm{i}}+ \\
& \beta_{4} \text { Property Rights Index }_{\mathrm{i}}+\beta_{5} \text { Market Size }_{i}+ \\
& \beta_{6} \text { Initial Foreign Participation }_{i}+\beta_{7}{ }^{\prime} \text { Regional Dummies }_{i}+\varepsilon_{\mathrm{i}} .
\end{aligned}
$$

$\Delta$ Foreign Participation is the change in the share of banking sector assets held by foreign banks in country $i$ between 1995 and 2002, based on the data from Micco et al. (2006). Crisis is a dummy variable equal to one if a country experienced a systemic banking crisis at any point during the period of study as defined in Caprio and Klingebiel (2003). Macro is a matrix of two variables, inflation and total output growth, intended to capture the attractiveness of an environment for prospective foreign entrants. Inflation is averaged over the period; output growth is the total change in real output from 1995 to 2002. ${ }^{9}$ We expect foreign bank participation to increase with GDP growth because it reflects opportunities for the profitable provision of financial services (especially lending), and to decrease with the level of inflation because it reflects uncertainty and, perhaps, macroeconomic mismanagement by the government. Both of those factors make medium and long-term lending problematic.

The Banking Index is taken from the Heritage Foundation which reports a yearly assessment of the level of banking restrictions in a country. As noted, the index ranges from 1 to 5 with higher scores indicating greater restrictions. Among the restrictions that the Heritage Foundation considers in constructing this index are the ease with which foreign banks can open branches and subsidiaries; government interference in the allocation of credit, including government ownership of banks; the ability of private banks to operate without government regulation such as deposit insurance; and the ability of banks to provide a wide range of financial services (including real estate and securities transactions, and insurance). We would expect that more restrictive environments would be less receptive to foreign bank participation. For their

\footnotetext{
${ }^{9}$ The construction of these variables is intended to minimize the influence of yearly observations that are outliers. In the fixed effects regressions in the next section, which are of necessity based on yearly observations, we remove observations for inflation and output growth on the tails of their respective distributions $\left(<1^{\text {st }}\right.$ percentile, $>99^{\text {th }}$ percentile).
} 
part, foreign banks would also likely find it unattractive to enter restrictive environments. Thus, we expect a negative relation between the Banking Index and Foreign Participation.

Property Rights Index measures the level of protection of private property in a country. Like the Banking Index, it ranges from 1 to 5 with lower values indicating better protection of property. In constructing this measure, the Heritage Foundation considers the extent to which the government protects and enforces laws to protect private property, the likelihood that the government will itself expropriate property, the existence of a commercial code, and the speed and efficacy of the judiciary in resolving contractual disputes. We expect foreign banks to be more prevalent in countries that better protect private property, and thus a negative relation between the index and foreign bank participation in the regressions that follow. ${ }^{10}$

In some specifications, we include a measure of market size, namely the log of GDP averaged from 1995 to 2002. Controlling for the quality of the macroeconomic environment and banking sector, foreign banks might find larger markets more attractive, and thus we expect a positive relationship between the log of GDP and foreign bank participation. We include the share of banking sector assets held by foreign-owned banks in 1995-96, Initial Foreign Participation, in some specifications to test whether foreign bank participation grew more rapidly in countries that had little foreign bank presence at the outset of the period. The intuition is that the process of foreign bank entry was already complete in countries with high foreign participation shares. We would therefore expect a negative relation between the level of foreign participation in 1995-96 and subsequent changes in foreign bank participation.

Finally, we include regional dummy variables in some specifications. As illustrated in the figures above, the level of foreign bank participation and its response to banking crises varied across regions, with relatively high levels in Africa, Latin America, and Eastern Europe and Central Asia as compared with East Asia and the Pacific, the Middle East and North Africa, and South Asia. Post-crisis increases in foreign bank participation also tended to be steeper in Africa, Latin America, and, especially, in Eastern Europe and Central Asia. We include the regional dummies to control for some of these differences in the evolution of foreign participation. We note, however, that these dummies are also likely to rob the banking crisis variable of some

\footnotetext{
${ }^{10}$ Two advantages of the Heritage indexes are that the underlying methodology has been consistent over time and the country coverage is wide. We can therefore construct a balanced panel that captures the same concepts over time for a wide array of countries.
} 
explanatory power since the occurrence and severity of crises also evince a regional pattern. We, therefore, view the models that include the regional dummies as a stricter test of the relationship between crises and foreign bank participation.

The main result from Table 5 is that countries that had banking crises tended to have larger increases in foreign bank participation than those did not. The banking crisis coefficient is significant at the ten percent level or better in all but one specification. In that model (column 4), it just misses significance. These findings confirm and expand upon those of Mathieson and Roldós (2001), who found a significant positive association between banking crises and various measures of foreign participation and foreign ownership of banks for fifteen countries over a shorter period (1995 to 1999). They find that, controlling for many of the same factors that we do in Table 5, foreign bank participation in 1999 (defined as we do) was 9.2 percentage points higher in countries that had a banking crisis. In our models, which are estimated over a much wider set of countries, foreign participation increased by 7.5 to 11.3 percentage points between 1995 and 2002 for countries that suffered a banking crisis.

As hypothesized, GDP growth is significantly positively related to foreign bank participation. In the specifications that include regional dummies $(3,4,7$, and 8$)$ inflation is negative, as hypothesized, though the coefficient does not achieve significance. In almost all cases, neither the banking restrictions index nor the insecurity of property rights index is significant. The exception is the banking restrictions coefficient in model 6, which has the expected negative sign. The insignificance of the banking and property rights indexes might be because better (i.e., lower) scores on those indexes also indicate a healthier environment for private domestic banks, making it more difficult for foreign banks to enter and compete.

The initial level of foreign bank participation is negative and approaches or achieves significance in all specifications in which it is included (columns 4-8), which suggests that it is a relevant control variable. The coefficients for the regional dummies reflect the foreign participation patterns described above, with Asia and the Middle East lagging the omitted region, Africa. As anticipated, the inclusion of the regional dummies, and also market size and initial foreign participation, reduces the significance and magnitude of the banking crisis variable to some extent. However, in our most complete specification (column 8), the coefficient is significant at ten percent and its magnitude ( 7.8 percentage points) is only slightly smaller than for the less complete models. The results in this sub-section indicate that, all else equal, banking 
crises are associated with increased foreign bank participation. Admittedly, however, crosssectional regressions are not ideal for assessing whether crises actually caused those increases because of the potential for relevant omitted country characteristics that might drive both foreign bank participation and crises.

\subsection{The Timing of Foreign Bank Participation: Regressions with Country Fixed Effects}

To address the concerns with cross-country regressions and to better understand the timing of changes in foreign bank participation as a result of crises, we conduct panel estimations following equations (2) and (2') below:

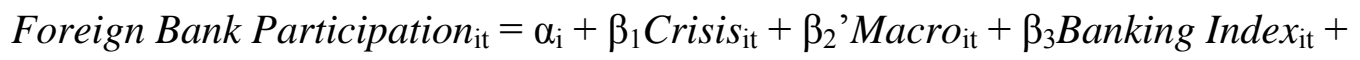

$\beta_{4}$ Property Rights Index $_{\mathrm{it}}+\beta_{5}$ Market Size $_{\mathrm{it}}+\beta_{6}{ }^{\prime}$ Year Dummies $_{\mathrm{it}}+\varepsilon_{\mathrm{it}}$.

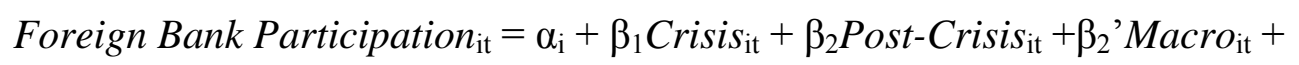

$\beta_{3}$ Banking Index $_{\mathrm{it}}+\beta_{4}$ Property Rights Index $_{\mathrm{it}}+\beta_{5}$ Market Size $_{\mathrm{it}}+$

$\beta_{6}{ }^{\prime}$ Year Dummies ${ }_{\text {it }}+\varepsilon_{\text {it }}$.

Both in (2) and (2'), $\alpha_{i}$ represents the average level of foreign bank participation for country $i$ over the period. Thus, coefficients in both equations indicate departures from country-specific mean participation levels that are associated with changes in our explanatory variables. Because we include country fixed effects in the regression, we can no longer include regional dummies as these do not vary over time. We can, however, include year dummies, which we do in some specifications. Because crises occurred in waves, the yearly dummies are likely to reduce the explanatory power of the banking crisis variable. It is therefore questionable whether they should be included. Finally, both in (2) and (2'), we include similar macro and institutional controls to those included in the cross-section regressions discussed above.

There is one important difference between equation (2) and (2'). In equation (2), the banking crisis variable is a dummy equal to one if a country was in crisis in a given year as defined by Caprio and Klingebiel (2003). For pre- and post-crisis years, the dummy is equal to zero. Thus, the banking crisis coefficient in equation (2) picks up a simple comparison between crisis and non-crisis years. Pre- and post-crisis years are lumped together as non-crisis years. To test separately whether crisis periods differ from pre-crisis and post-crisis years, we estimate equation ( 2 '). In that equation, we include a new crisis variable equal to one from the onset of the 
crisis onwards. Furthermore, we introduce a post-crisis dummy equal to one beginning in the year after Caprio and Klingebiel (2003) determined a crisis to have ended. The coefficient for the new crisis variable measures the level shift in foreign bank participation relative to the pre-crisis period, while the post-crisis dummy reflects the shift relative to the crisis period.

In Table 6, columns (1)-(4) reflect the specifications following equation (2) where the crisis dummy identifies periods of crisis vis-à-vis all other periods (i.e., post and pre-crisis periods are lumped together). In the specifications that exclude the year dummies (columns 1 and 2 ), the level of foreign bank participation is 6-7 percentage points lower in crisis years. When we introduce the year dummies in columns (3) and (4), the reduction in foreign bank participation is only 2.2-2.4 percentage points, but the crisis variable remains significant at the ten percent level.

Columns (5)-(8) of Table 6 correspond to equation (2'). In this case, we separately control for crisis and post-crisis periods. When we do this, the crisis coefficient in models (5)-(8) is insignificant except for the positive, marginally significant coefficient in model (5). These results indicate that foreign banks did not reduce their participation in crisis years. Moreover, the positive significant coefficients for the post-crisis dummy in models (5)-(7) indicate that the steep increase in foreign participation occurred after crises had passed. In model (8), the postcrisis dummy is positive, but it does not achieve significance. Again, however, there are good reasons to exclude the year dummies from these specifications, in which case the most relevant model is (6), which shows a strong association between foreign participation and the post-crisis dummy. In addition, in model (8) the bank crisis dummy is negative and nearly significant. We can therefore nearly reject the null that the crisis and post-crisis dummies are equal to each other (F-statistic 2.13, p-value 0.12) for that model.

In short, models (5)-(8) indicate that foreign banks did not retreat during crises, and increased their participation in the aftermath of crises. Thus, the negative crisis coefficients in models (1)-(4) are attributable to the high levels of foreign participation in post-crisis years rather than low levels in crisis years (relative to pre-crisis years).

Many of the control variables are more highly significant in the fixed effects regressions in Table 6 than they were in the cross-country regressions in Table 5. For example, inflation is significantly negatively related to foreign participation in all models in which it appears, as hypothesized. Similarly, the coefficients for restrictions in banking and the insecurity of property rights are significant and negative in multiple specifications. However, GDP growth is not 
robustly associated with foreign bank participation, and the negative significant coefficient in model (4) is unexpected. This could be due to collinearity between GDP growth and other regressors (most notably inflation).

Discussions about whether foreign banks have behaved opportunistically in response to crises are often inconclusive because they hinge on how opportunism is defined, which requires subjectivity. For example, if one defines as opportunistic foreign banks' profiting from their participation in stable periods and retreating during crises, the results in this section indicate that they have not behaved opportunistically. However, our results could be consistent with foreign banks acquiring cheap domestic banking assets as a result of crises, which could be viewed as opportunistic. We refrain from drawing that conclusion for two reasons. First, the acquisition of distressed banking assets (e.g., from intervened banks) by foreign interests is often viewed as beneficial by regulators and supervisors coping with the aftermath of a crisis. Indeed, those officials often look to foreign investors to help re-capitalize their banking sectors because they lack other options due to the fiscal constraints discussed above. Second, the post-crisis increase in foreign participation might not be due to acquisitions or de novo entry, but to more rapid growth of the assets of the pre-crisis roster of foreign banks relative to domestic ones.

\subsection{Foreign Participation, Crises, and Private Credit}

One potential negative by-product of crises is the destruction of information generated via long-term relationships between borrowers and failed banks. Even in the case where banks are not closed but are merged or acquired, a disruption in lending relationships might result from the restructuring and reorganization that typically takes place within banks following mergers and acquisitions. Since they are at a relative disadvantage in local knowledge, foreign banks, and particularly recent entrants, might not be well suited to reconstituting such relationships. Thus, while our evidence indicates that the asset share of foreign banks has increased after crises, it does not necessarily follow that greater participation has gone hand in hand with more lending. In this section, therefore, we examine whether foreign bank participation coincided with increased provision of credit to the private sector, especially after crises.

We use fixed-country-effects specifications similar to those in Table 6, except that the level of private credit relative to GDP is the dependent variable: 


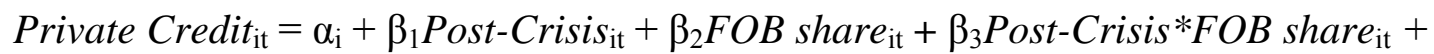

$\beta_{6}{ }^{\prime}$ Macro $_{\mathrm{it}}+\beta_{6}$ Banking Index $_{\mathrm{it}}+\beta_{7}$ Property Rights $_{\mathrm{it}}+\beta_{8}$ Market Size $_{\mathrm{it}}+$ $\beta_{9}{ }^{\prime}$ Year Dummies ${ }_{\text {it }}+\varepsilon_{\mathrm{it}}$.

In equation (3), we include the post-crisis dummy variable on its own (i.e., without the crisis dummy) because that is the most likely period for recovery in lending. FOB share is the share of banking sector assets held by foreign-owned banks. This variable is included to test whether foreign bank participation was associated with higher levels of credit to the private sector. We also interact FOB share with the post-crisis dummy to test whether the association between foreign bank participation and private credit remained the same after crisis. In some specifications, we include the share of banking sector assets held by the top 3 banks in each country because sector concentration could lead to higher interest rates and less lending.

The positive significant coefficients for the post-crisis variable in columns 1 and 2 indicate that private credit levels tends to be higher in the aftermaths of crises, which could be taken as a sign of recovery. In addition, the positive, significant coefficients for FOB Share in those specifications indicate that increased foreign participation is associated with higher levels of private credit (relative to each country's average private credit level over the period). However, the negative significant coefficient for the FOB*post-crisis interaction is similar in magnitude to the positive FOB share coefficient. Thus, the positive association between foreign participation and the extension of credit to the private sector pertains only to the pre-crisis and crisis periods.

Because these results might be driven by how we specified the post-crisis dummy variable, columns (5) and (6) use the crisis and post-crisis dummies that we used in Table 6 in the regressions above. Inclusion of both of those dummies provides a more precise comparison between private credit levels in the pre-crisis, crisis, and post-crisis periods. Though the crisis dummy is positive and weakly significant in one specification, the post-crisis dummies remain positive and highly significant, indicating that the increase in private credit levels occurred in the post-crisis period. The pre-crisis and crisis periods tend to be statistically indistinguishable from one another. With the inclusion of the crisis dummy the foreign bank participation variable remains positive, though it loses some significance. The FOB*post-crisis interaction remains negative and highly significant. If anything, the results in columns (5) and (6) provide a stronger 
suggestion that, in the aftermath of crises, high foreign bank participation levels are associated with lower private credit levels.

Does this imply that foreign banks pull back from lending as a result of crisis? Not necessarily because, as noted above, it could be that foreign banks are acquiring distressed banks with relatively weak loan portfolios. Many of those loans are written off in restructuring exercises prior to the sale of banks to foreign investors, and thus the reduction in private credit is a mechanical accounting exercise rather than a reflection of slow post-crisis credit growth. The negative, significant results for the FOB*post-crisis interaction could be picking up these selection effects.

To test for that possibility, we try to distinguish between established banks and recent entrants by introducing a new variable: the interaction between the level of foreign participation at the beginning of the sample period and the post-crisis dummy. If FOB share is close to initial $F O B$, the level of foreign participation has remained relatively constant throughout the sample period. In those environments, we hypothesize that foreign banks are better established. By contrast, environments where foreign participation is much higher than it was initially are likely to be characterized by the recent acquisitions of distressed banks described above. We expect therefore that the negative association between foreign participation and private credit in the post-crisis period will be smaller (in absolute value) in countries where initial and post-crisis foreign participation levels are close to one another. In other words, if our conjectures are correct, we expect a positive coefficient on the initial FOB*post-crisis interaction.

In columns (3) and (4) of Table 7, we include the initial FOB interaction in specifications with only one crisis variable, the post-crisis dummy. That dummy remains positive and significant. FOB share remains positive in those specifications, while the FOB*post-crisis variables remains negative. Both are highly significant. As hypothesized, the initial FOB*postcrisis interaction is positive and significant. When $F O B$ share and initial FOB are equivalent, the two interaction terms roughly cancel out one another. In those cases, there is no post-crisis reduction in private credit, and thus the positive association between FOB share and private credit holds for all periods (pre-crisis, crisis, and post-crisis). The same pattern holds when we introduce the crisis dummy in columns (7) and (8). In short, these results are consistent with the idea that post-crisis reductions in private credit in countries with high levels of foreign bank participation are due the recent acquisitions of troubled domestic banks. We cannot, however, 
rule out the possibility that the newly arrived banks are simply poorer financial intermediaries for the private sector. In environments where foreign banks are better established, there is no such reduction. Indeed, foreign participation appears to have a positive effect on private credit provision regardless of the occurrence of crises.

One might object to our characterizing all environments where foreign participation remained relatively constant as having relatively well-established foreign banks. In some countries, foreign participation remained negligible throughout the period, and thus foreign participation should have had little or no effect on private credit levels. To test whether it is countries with low, stable levels of foreign participation that are responsible for the results in Table 8, we restrict the sample to countries that exceeded various thresholds of initial foreign participation $(5 \%, 10 \%$, and $20 \%)$. Because it splits the sample into groups of roughly equal size, the results for the 10\% threshold appear in Table 8. Qualitative results are similar for the 5\% and $20 \%$ thresholds.

The pattern of significant results found in Table 8 - i.e., positive for FOB share, negative for FOB*post-crisis, and positive for initial FOB*post-crisis - is only found for countries that had initial foreign participation above 10\% (Table 8, columns (1) and (2)). For countries with initial participation less than $10 \%$ (columns (3) and (4)), none of the foreign bank participation variables are significant. Therefore, the results in Table 7 are being driven by countries that had reasonably high levels of foreign participation, and, within that group, the positive relationship between foreign participation and private credit is due to those with participation levels that remained relatively constant over time. The results in Table 8 , therefore, provide additional support for the idea that, in the aftermath of crises, better established foreign banks provide more credit to the private sector than recent foreign entrants, perhaps because those entrants tend to acquire distressed banks. For countries with low levels of participation, the foreign ownership variables explain little variation in private credit levels, as one would expect. ${ }^{11}$

To summarize the results from this section, we find that countries that experienced at least one banking sector crisis from 1995 to 2002 tended to have more foreign bank participation

\footnotetext{
${ }^{11}$ It is interesting to note that the post-crisis dummy is significant only for the countries that had low levels of initial foreign bank participation. This suggests that the recovery in lending in those environments is due primarily to domestic banks. In countries with high levels of initial participation, the post-crisis dummy is insignificant, indicating no such rebound. Again, however, the positive significant coefficient for FOB share indicates that private credit levels are higher during both crisis and non-crisis periods (at least, that is, for countries with relatively stable foreign bank participation levels). In this sense, foreign bank participation can be viewed as a stabilizing influence on private credit levels.
} 
than those that did not. Moreover, the timing of the increases indicates that foreign participation often increased in response to crises. However, post-crisis increases in foreign participation do not appear to be associated with improved provision of private credit. We hypothesize that this could be because recent foreign entrants tend to acquire distressed banks with loan portfolios in need of deep restructuring (i.e., write-offs). We cannot, however, rule out the possibility that the new entrants are simply poor intermediaries for the private sector. By contrast, countries with reasonably high and stable levels of foreign participation tend to have higher private credit levels than others before, during, and after crises.

One might also expect that the competitive pressure stemming from stable foreign participation would enhance banking sector efficiency. To test that proposition, we tried regressions with two dependent variables: net interest margin and the ratio of overhead costs to total assets. We could uncover no robust relationships between those measures, foreign participation, and the occurrence of crisis. This might be because those measures are imperfect proxies for efficiency, especially in a cross-country context. It might also be that efficiency improvements take longer to manifest themselves, and thus our time period is too short to detect them. It seems likely, however, that the post-crisis effects of foreign participation on banking sector efficiency are best detected in detailed micro-level studies of individual countries.

\section{Conclusions}

This paper describes the recent trends in foreign bank ownership in developing countries, summarizes the existing evidence on the causes and implications of foreign bank presence and re-examines the link between banking crises and foreign bank participation. We find that foreign bank participation has risen strongly in two regions of the world: Eastern Europe and Central Asia and Latin America. Foreign bank presence has increased in Africa as well, but at a generally slower pace than in the other two regions. By contrast, foreign bank participation has remained stagnant or even declined in East and South Asia and in the Middle East and North Africa.

The literature on the drivers of foreign bank participation points to factors such as market opportunities, and cultural, regulatory and institutional similarities. In terms of the implications of foreign bank participation, the existing evidence suggests that foreign banks tend to foster efficiency and competition in the sector (except in cases of high banking concentration or when 
restrictions on banking activities are present), and bolster banking sector stability, but may or may not improve access to credit.

Our empirical analysis shows that countries that experienced a banking crisis from 1995 to 2002 tended to have higher levels of foreign bank participation than those that did not. Additional regressions indicate that foreign participation tended to increase as a result of crises rather than prior to them. However, those post-crisis increases in foreign participation did not coincide with improved provision of credit to the private sector. We speculate that this was because foreign entrants acquired distressed banks with a high share of loans that needed to be written off. By contrast, in countries where the level of foreign participation was relatively high and stable, private credit levels were significantly higher than in other countries before, during, and after crises. 


\section{References}

Ball, C.A. and Tschoegl, A. E., 1982. "The Decision to Establish a Foreign Branch or Subsidiary: An Application of Binary Classification Procedures." Journal of Financial and Quantitative Analysis 17 (3), 411-24.

Barajas, A., Steiner, R. and Salazar, N., 2000. "The Impact of Liberalization and Foreign Investment in Colombia's Financial Sector." Journal of Development Economics 63(1), 157-196.

Berger, A., Klapper, L. and Udell, G., 2001. "The Ability of Banks to Lend to Informationally Opaque Small Businesses.” Journal of Banking and Finance 25, 2127-2167.

Buch, C., 2003. "Information or Regulation: What Drives the International Activities of Commercial Banks?" Journal of Money, Credit and Banking 35(6), 851-869.

Buch, C. and DeLong G., 2004. "Cross Border Bank Merger: What Lures the Rare Animal?" Journal of Banking and Finance 28(9), 2077-2102.

Buch, C. and Lipponer A., 2004. "FDI versus Cross-Border Financial Services: The Globalization of German Banks.” Discussion Paper Series 1: Studies of the Economic Research Centre No 05/2004.

Caprio, G. and Klingebiel, D., 2003. "Episodes of Systematic and Borderline Financial Crises." The World Bank. Mimeo.

Cho, K.R., Krishnan, S. and Nigh, D., 1987. "The State of Foreign Banking Presence in the United States." International Journal of Bank Marketing 5(2), 59-75.

Claessens, S., Demirguc-Kunt, A. and Huizinga, H., 2001. "How Does Foreign Entry Affect Domestic Banking Markets?” Journal of Banking and Finance 25 (5), 891-911.

Claessens, S. and Laeven, L., 2003. "What Drives Bank Competition? Some International Evidence." Journal of Money, Credit and Banking 36(3), 563-83.

Claessens, S. and Lee, J. K., 2003. "Foreign Banks in Low-Income Countries: Recent Developments and Impacts." in Hanson, J., Honohan, P. and Majnoni, G. (eds.). Globalization and National Financial Systems. The World Bank, Washington D.C.

Claessens, S. and Van Horen, N., 2006. "Location Decisions of Foreign Banks and Competitive Advantage.” The World Bank, Mimeo.

Clarke, G., Cull, R., Martinez Peria, M.S. and Sanchez, S, 2003. "Foreign Bank Entry: Experience, Implications for Developing Economies, and Agenda for Further Research." The World Bank Research Observer 18 (1), 25-59. 
Clarke, G., Cull, R., Martinez Peria, M.S. and Sanchez, S., 2005. "Bank Lending to Small Businesses in Latin America: Does Bank Origin Matter?" Journal of Money, Credit, and Banking 37 (1), 83-118.

Clarke, G., Cull, R. and Martinez Peria, M.S., 2006. "Foreign Bank Participation and Access to Credit Across Firms in Developing Countries." Journal of Comparative Economics 34, 774-795.

Crystal, J., Dages, G. and Goldberg, L., 2001. "Does Foreign Ownership Contribute to Sounder Banks in Emerging Markets? The Latin American Experience.” in Litan, R.E., Masson, P. and Pomerleano, M. (eds.) Open Doors: Foreign Participation in Financial Systems in Developing Countries. Washington, D.C.: Brooking Institution Press.

De Hass, R. and Van Lelyveld, I., 2006. "Foreign Banks and Credit Stability in Central and Eastern Europe. A Panel Data Analysis.” Journal of Banking and Finance 30, 1927-1952.

Denizer, C., 2000. "Foreign Entry in Turkey's Banking Sector, 1980-1997." in Claessens, S. and Jansen, M. (eds.). The Internationalization of Financial Services: Issues and Lessons for Developing Countries. Boston. Kluwer Academic.

Detragiache, E. and Gupta, P., 2006. "Foreign Banks in Emerging Market Crises: Evidence from Malaysia." Journal of Financial Stability 2(3), 217-242.

Detragiache, E., Gupta, P. and Tressel, T., 2005. "Foreign Banks in Poor Countries: Theory and Evidence.” IMF Working Paper No. 06/18. Washington, DC.

Fisher, A. and Molyneaux, P., 1996. "A Note on the Determinants of Foreign Bank Activity in London Between 1980-1989.” Applied Financial Economics, 6 (3), 271-77.

Focarelli, D. and Pozzolo, A., 2001. "The Patterns of Cross-Border Bank Mergers and Shareholdings in OECD Countries." Journal of Banking and Finance, Vol. 25 (12), 2305-2337.

Galindo, A., Micco, A. and Serra, C., 2003. "Better the Devil That You Know: Evidence on Entry Costs Faced By Foreign Banks.” IDB - Research Department Working Paper No.477.

Gianneti, M. and Ongena, S., 2005. "Financial Integration and Entrepreneurial Activity: Evidence from Foreign Bank Entry in Emerging Markets.” ECB Working Paper No. 498 (June).

Golberg, L., 2002. "When is U.S. Bank Lending to Emerging Markets Volatile?" in Edwards, S. and Frankel, J. (eds.) Preventing Currency Crises in Emerging Markets. NBER Working Paper No. 8209.

Goldberg, L., Dages, B.G., and Kinney, D., 2000. "Foreign and Domestic Bank Participation in Emerging Markets: Lessons from Mexico and Argentina." Economic Policy Review 6(3). Federal Reserve Bank of New York. 
Goldberg, L.G. and Grosse, R., 1994. "Location Choice of Foreign Bank in the United States." Journal of Economics and Business 46(5), 367-79.

Goldberg, L.G. and Johnson, D., 1990. "The Determinants of U.S. Banking Activity Abroad." Journal of International Money and Finance 9 (2), 123-37.

Goldberg, L.G. and Saunders, A., 1980. "The Causes of U.S. Bank Expansion Overseas: The Case of Great Britain.” Journal of Money, Credit and Banking 12(4), 630-43.

Goldberg, L.G. and Saunders, A., 1981a. "The Determinants of Foreign Banking Activity in the United States." Journal of Banking and Finance 5(1), 17-32.

Goldberg, L.G. and Saunders, A., 1981b. “The Growth of Organizational Forms of Foreign Banks in the U.S.: A Note.” Journal of Money, Credit and Banking 13(3), 365-74.

Haber, S. and Musacchio, A., 2005. "Contract Rights and Risk Aversion: Foreign Banks and the Mexican Economy, 1997-2000.” Stanford University. Mimeo.

Honohan, P. and Klingebiel, D., 2003. "The Fiscal Cost Implications of an Accommodating Approach to Banking Crises.” Journal of Banking and Finance 27(8), 1539-1560.

Hultman, C. W. and McGee, R., 1989. "Factors Affecting the Foreign Banking Presence in the United States." Journal of Banking and Finance 13(3), 383-96.

Levy Yeyati, E. and Micco, A., 2007. "Concentration and Foreign Penetration in Latin American Banking Sectors: Impact on Competition and Risk." Journal of Banking and Finance. Forthcoming.

Martinez Peria, M. S. and Mody, A., 2004. "How Foreign Participation and Market Concentration Impact Bank Spreads: Evidence from Latin America." Journal of Money, Credit, and Banking 36 (3), 511-537.

Martinez Peria, M.S., Powell, A. and Vladkova-Hollar, I., 2005. "Banking on Foreigners: The Behavior of International Bank Claims on Latin America, 1985-2000.” IMF Staff Paper 53(3). Washington DC.

Mathieson, D.J. and Roldós, J., 2001. "Foreign Bank in Emerging Markets." in Litan, R.E., Masson, P. and Pomerleano, M. (eds.) Open Doors: Foreign Participation in Financial Systems in Developing Countries. Washington, D.C.: Brooking Institution Press.

Mian, A., 2006. "Distance Constraints: The Limits of Foreign Lending in Poor Economies." Journal of Finance 61(3), 1465-1505.

Micco, A., Panizza, U. and Yañez, M., 2006. "Bank Ownership and Performance: Does Politics Matter?" Journal of Banking and Finance. Forthcoming. 
Miller, S. R. and Parkhe, A., 1998. "Patterns on the Expansion of U.S. Banks' Foreign Operations." Journal of International Business Studies 29(2), 359-90.

Moreno, R. and Villar, A., 2006. "The Increased Role of Foreign Bank Entry in Emerging Markets.” BIS Papers No 23.

Nigh, D., Cho, K. R. and Krishnan, S., 1986. "The Role of Location-Related Factors in U.S. Banking Involvement Abroad: An Empirical Analysis." Journal of International Business Studies 17, 59-72.

Panzar, J.C. and Rose, J.N., 1987. "Testing for "Monopoly" Equilibrium." Journal of Industrial Economics 35, 443-457.

Peek, J. and Rosengren, E., 2000. "Implications of the Globalization of the Banking Sector: The Latin American Experience." New England Economic Review, September/October. Federal Reserve Bank of Boston.

Schulz, H., 2006. "Foreign Banks in Mexico: New Conquistadors or Agents of Change?" The Wharton School, Financial Institutions Center, Working Paper No. 06-11. University of Pennsylvania.

Tschoegl, A.E., 2003. "Financial Crises and the Presence of Foreign Banks." The Wharton School, Financial Institutions Center Working Paper 03-35.

Uiboupin, J., 2004. "Effects of Foreign Banks Entry on Bank Performance in the CEE Countries." Working Paper No. 33-2004. University of Tartu Faculty of Economics and Business Administration.

Unite, A.A. and Sullivan, M. J., 2002. "The Effect of Foreign Entry and Ownership Structure on the Philippine Domestic Banking Sector.” Journal of Banking and Finance 27, 2249-2271. 
Table 1. Foreign Bank Participation in Developing Countries 1995-2002

Table shows the share of assets (as a percentage of total banking sector assets) held by foreign banks

\begin{tabular}{|c|c|c|c|c|c|c|c|c|}
\hline & 1995 & 1996 & 1997 & 1998 & 1999 & 2000 & 2001 & 2002 \\
\hline DEVELOPING COUNTRIES & $18.1 \%$ & $18.5 \%$ & $21.2 \%$ & $22.6 \%$ & $24.5 \%$ & $28.9 \%$ & $30.5 \%$ & $32.7 \%$ \\
\hline East Asia \& Pacific & $15.0 \%$ & $14.5 \%$ & $15.1 \%$ & $14.6 \%$ & $12.6 \%$ & $8.2 \%$ & $7.7 \%$ & $11.7 \%$ \\
\hline Cambodia & & & & & & $8.5 \%$ & $8.3 \%$ & $7.9 \%$ \\
\hline China & $0.0 \%$ & $0.0 \%$ & $0.0 \%$ & $0.0 \%$ & $0.0 \%$ & $0.0 \%$ & $0.1 \%$ & $0.2 \%$ \\
\hline Indonesia & $4.4 \%$ & $4.7 \%$ & $5.8 \%$ & $6.0 \%$ & $3.0 \%$ & $5.7 \%$ & $4.1 \%$ & $3.9 \%$ \\
\hline Korea, Rep. & $2.1 \%$ & $2.1 \%$ & $2.2 \%$ & $5.0 \%$ & $4.7 \%$ & $7.6 \%$ & $4.9 \%$ & $9.2 \%$ \\
\hline Malaysia & $24.9 \%$ & $24.9 \%$ & $25.0 \%$ & $26.0 \%$ & $23.1 \%$ & $25.4 \%$ & $22.7 \%$ & $22.8 \%$ \\
\hline Mongolia & & & & & $0.0 \%$ & $7.1 \%$ & $11.3 \%$ & $45.3 \%$ \\
\hline Papua New Guinea & $71.7 \%$ & $67.0 \%$ & $70.3 \%$ & $63.9 \%$ & $63.1 \%$ & & & \\
\hline Philippines & $7.9 \%$ & $8.2 \%$ & $8.5 \%$ & $8.3 \%$ & $8.6 \%$ & $9.4 \%$ & $9.8 \%$ & $8.3 \%$ \\
\hline Thailand & $7.2 \%$ & $6.9 \%$ & $7.1 \%$ & $6.5 \%$ & $10.2 \%$ & $9.0 \%$ & $7.3 \%$ & $6.7 \%$ \\
\hline Vietnam & $1.4 \%$ & $1.8 \%$ & $1.7 \%$ & $1.0 \%$ & $0.8 \%$ & $1.0 \%$ & $1.0 \%$ & $0.9 \%$ \\
\hline Europe \& Central Asia & $13.0 \%$ & $13.3 \%$ & $14.7 \%$ & $18.2 \%$ & $21.1 \%$ & $28.4 \%$ & $32.7 \%$ & $35.7 \%$ \\
\hline Albania & & & & & & $10.9 \%$ & $15.6 \%$ & $19.7 \%$ \\
\hline Armenia & & & $17.6 \%$ & $24.6 \%$ & $34.9 \%$ & $49.3 \%$ & $60.1 \%$ & $59.1 \%$ \\
\hline Azerbaijan & $0.0 \%$ & $0.0 \%$ & $0.0 \%$ & $0.0 \%$ & $0.0 \%$ & $0.0 \%$ & $0.0 \%$ & \\
\hline Belarus & $0.0 \%$ & $0.0 \%$ & $0.0 \%$ & $7.2 \%$ & $4.3 \%$ & $3.8 \%$ & $8.4 \%$ & $9.5 \%$ \\
\hline Bosnia and Herzegovina & & $5.3 \%$ & $6.5 \%$ & $7.4 \%$ & $12.4 \%$ & $34.0 \%$ & $46.1 \%$ & $45.1 \%$ \\
\hline Bulgaria & $8.2 \%$ & $10.3 \%$ & $10.3 \%$ & $19.5 \%$ & $30.9 \%$ & $70.1 \%$ & $55.5 \%$ & $51.7 \%$ \\
\hline Croatia & $9.8 \%$ & $13.6 \%$ & $14.1 \%$ & $14.6 \%$ & $15.8 \%$ & $19.1 \%$ & $20.6 \%$ & $42.1 \%$ \\
\hline Czech Republic & $14.2 \%$ & $10.6 \%$ & $13.7 \%$ & $17.3 \%$ & $31.0 \%$ & $48.9 \%$ & $61.4 \%$ & $58.7 \%$ \\
\hline Estonia & $80.7 \%$ & $78.9 \%$ & $72.1 \%$ & $74.0 \%$ & $73.5 \%$ & $73.1 \%$ & $73.0 \%$ & $72.7 \%$ \\
\hline Georgia & & $10.6 \%$ & $7.7 \%$ & $6.4 \%$ & $4.8 \%$ & $20.0 \%$ & $35.8 \%$ & $36.2 \%$ \\
\hline Hungary & $22.4 \%$ & $23.1 \%$ & $42.1 \%$ & $62.9 \%$ & $67.8 \%$ & $63.5 \%$ & $63.3 \%$ & $58.7 \%$ \\
\hline Kazakhstan & $12.6 \%$ & $10.6 \%$ & $15.8 \%$ & $18.7 \%$ & $18.6 \%$ & $11.7 \%$ & $12.6 \%$ & $20.0 \%$ \\
\hline Kyrgyz Republic & & & & & & $30.3 \%$ & $33.3 \%$ & $20.8 \%$ \\
\hline Latvia & $17.8 \%$ & $30.4 \%$ & $32.7 \%$ & $35.3 \%$ & $37.0 \%$ & $37.6 \%$ & $38.6 \%$ & $38.8 \%$ \\
\hline Lithuania & $18.9 \%$ & $28.4 \%$ & $35.5 \%$ & $36.9 \%$ & $41.8 \%$ & $62.5 \%$ & $92.2 \%$ & $91.3 \%$ \\
\hline Macedonia, FYR & $28.4 \%$ & $27.1 \%$ & $25.8 \%$ & $23.3 \%$ & $23.6 \%$ & $47.8 \%$ & $43.8 \%$ & $41.8 \%$ \\
\hline Moldova & & $1.6 \%$ & $1.8 \%$ & $1.8 \%$ & $2.5 \%$ & $7.9 \%$ & $18.8 \%$ & $18.3 \%$ \\
\hline Poland & $3.7 \%$ & $8.4 \%$ & $13.8 \%$ & $27.1 \%$ & $34.1 \%$ & $37.8 \%$ & $50.7 \%$ & $49.3 \%$ \\
\hline Romania & $0.0 \%$ & $0.2 \%$ & $0.5 \%$ & $12.9 \%$ & $17.2 \%$ & $25.9 \%$ & $27.0 \%$ & $26.5 \%$ \\
\hline Russian Federation & $2.0 \%$ & $1.4 \%$ & $2.7 \%$ & $2.1 \%$ & $4.5 \%$ & $11.5 \%$ & $13.7 \%$ & $15.6 \%$ \\
\hline Serbia and Montenegro & & & & & & $0.0 \%$ & $0.0 \%$ & $0.0 \%$ \\
\hline Slovak Republic & $8.7 \%$ & $11.9 \%$ & $18.0 \%$ & $20.4 \%$ & $21.5 \%$ & $54.6 \%$ & $56.6 \%$ & $81.5 \%$ \\
\hline Slovenia & $6.8 \%$ & $6.5 \%$ & $6.4 \%$ & $6.5 \%$ & $6.1 \%$ & $10.3 \%$ & $14.3 \%$ & $25.8 \%$ \\
\hline Turkey & $0.4 \%$ & $0.3 \%$ & $0.3 \%$ & $0.4 \%$ & $0.5 \%$ & $0.9 \%$ & $1.8 \%$ & $1.8 \%$ \\
\hline Ukraine & $0.0 \%$ & $0.0 \%$ & $0.0 \%$ & $0.0 \%$ & $2.3 \%$ & $5.8 \%$ & $6.2 \%$ & $6.8 \%$ \\
\hline Uzbekistan & & & $0.0 \%$ & $0.0 \%$ & $0.0 \%$ & $0.6 \%$ & $0.6 \%$ & $0.8 \%$ \\
\hline Latin America \& Caribbean & $19.3 \%$ & $19.4 \%$ & $24.3 \%$ & $25.0 \%$ & $25.4 \%$ & $29.6 \%$ & $30.2 \%$ & $33.2 \%$ \\
\hline Antigua and Barbuda & & & & & & $0.0 \%$ & $0.0 \%$ & $0.0 \%$ \\
\hline Argentina & $25.6 \%$ & $28.1 \%$ & $36.7 \%$ & $40.0 \%$ & $39.6 \%$ & $47.8 \%$ & $44.2 \%$ & $37.5 \%$ \\
\hline Bolivia & $42.7 \%$ & $40.5 \%$ & $39.7 \%$ & $44.4 \%$ & $44.2 \%$ & $40.9 \%$ & $39.4 \%$ & $39.4 \%$ \\
\hline Brazil & $9.0 \%$ & $9.7 \%$ & $14.4 \%$ & $15.1 \%$ & $17.3 \%$ & $26.4 \%$ & $30.4 \%$ & $27.9 \%$ \\
\hline Chile & $31.0 \%$ & $35.3 \%$ & $36.0 \%$ & $37.6 \%$ & $38.8 \%$ & $38.4 \%$ & $40.0 \%$ & $44.8 \%$ \\
\hline Colombia & $6.3 \%$ & $10.9 \%$ & $15.9 \%$ & $18.0 \%$ & $16.4 \%$ & $25.8 \%$ & $21.1 \%$ & $17.4 \%$ \\
\hline Costa Rica & $0.0 \%$ & $0.2 \%$ & $0.6 \%$ & $5.1 \%$ & $5.0 \%$ & $18.0 \%$ & $18.4 \%$ & $18.8 \%$ \\
\hline Dominican Republic & $11.1 \%$ & $10.8 \%$ & $9.9 \%$ & $2.0 \%$ & $17.5 \%$ & $16.2 \%$ & $17.7 \%$ & $17.5 \%$ \\
\hline Ecuador & & & $26.0 \%$ & $27.4 \%$ & $28.2 \%$ & $0.0 \%$ & $0.0 \%$ & $0.0 \%$ \\
\hline El Salvador & $1.0 \%$ & $1.8 \%$ & $2.9 \%$ & $8.3 \%$ & $8.3 \%$ & $13.6 \%$ & $13.5 \%$ & $14.2 \%$ \\
\hline Guatemala & $6.0 \%$ & $5.6 \%$ & $6.1 \%$ & $6.3 \%$ & $7.0 \%$ & $8.4 \%$ & $8.6 \%$ & $8.1 \%$ \\
\hline Guyana & $0.0 \%$ & $0.0 \%$ & $24.7 \%$ & $27.5 \%$ & $26.7 \%$ & $23.5 \%$ & $23.6 \%$ & $23.1 \%$ \\
\hline Haiti & & & & $0.0 \%$ & $0.0 \%$ & & & \\
\hline Honduras & $2.3 \%$ & $2.1 \%$ & $2.1 \%$ & $1.5 \%$ & $1.5 \%$ & $4.4 \%$ & $5.0 \%$ & $5.8 \%$ \\
\hline Jamaica & $24.3 \%$ & $21.2 \%$ & $32.9 \%$ & $35.8 \%$ & $21.9 \%$ & $18.9 \%$ & $19.3 \%$ & $50.3 \%$ \\
\hline Mexico & $2.3 \%$ & $4.3 \%$ & $7.2 \%$ & $7.5 \%$ & $9.9 \%$ & $28.5 \%$ & $30.0 \%$ & $61.9 \%$ \\
\hline Nicaragua & $0.7 \%$ & $1.4 \%$ & $3.0 \%$ & $3.9 \%$ & $3.8 \%$ & $5.1 \%$ & $4.3 \%$ & $4.4 \%$ \\
\hline Panama & $59.7 \%$ & $54.9 \%$ & $51.5 \%$ & $50.8 \%$ & $48.4 \%$ & $64.9 \%$ & $64.2 \%$ & $58.1 \%$ \\
\hline Paraguay & $69.3 \%$ & $56.2 \%$ & $73.9 \%$ & $76.8 \%$ & $77.2 \%$ & $79.9 \%$ & $81.7 \%$ & $83.3 \%$ \\
\hline Peru & $51.7 \%$ & $59.5 \%$ & $63.1 \%$ & $66.1 \%$ & $64.8 \%$ & $66.1 \%$ & $66.7 \%$ & $86.4 \%$ \\
\hline Trinidad and Tobago & $14.0 \%$ & $13.5 \%$ & $16.2 \%$ & $17.1 \%$ & $17.7 \%$ & $11.2 \%$ & $10.4 \%$ & $10.4 \%$ \\
\hline Uruguay & $24.3 \%$ & $14.2 \%$ & $18.1 \%$ & $24.4 \%$ & $30.6 \%$ & $91.8 \%$ & $95.5 \%$ & $94.5 \%$ \\
\hline Venezuela, RB & $4.8 \%$ & $17.4 \%$ & $29.1 \%$ & $33.7 \%$ & $34.3 \%$ & $20.7 \%$ & $30.2 \%$ & $26.6 \%$ \\
\hline
\end{tabular}

Data source: Micco, Panizza, and Yañez (2006) 
Table 1. Foreign Bank Participation in Developing Countries 1995-2002 (cont.)

Table shows the share of assets (as a percentage of total banking sector assets) held by foreign banks

\begin{tabular}{|c|c|c|c|c|c|c|c|c|}
\hline & 1995 & 1996 & 1997 & 1998 & 1999 & 2000 & 2001 & 2002 \\
\hline Middle East \& North Africa & $11.9 \%$ & $12.3 \%$ & $12.5 \%$ & $12.8 \%$ & $12.8 \%$ & $14.4 \%$ & $15.9 \%$ & $18.8 \%$ \\
\hline Algeria & & & & & & $59.0 \%$ & $67.5 \%$ & $60.0 \%$ \\
\hline Egypt, Arab Rep. & $4.0 \%$ & $6.0 \%$ & $6.1 \%$ & $6.1 \%$ & $6.2 \%$ & $6.9 \%$ & $6.4 \%$ & $7.1 \%$ \\
\hline Iran, Islamic Rep. & & & & & & $0.0 \%$ & $0.0 \%$ & \\
\hline Jordan & $12.8 \%$ & $12.4 \%$ & $12.9 \%$ & $12.8 \%$ & $12.8 \%$ & $13.5 \%$ & $13.7 \%$ & $13.3 \%$ \\
\hline Lebanon & $29.6 \%$ & $29.4 \%$ & $29.4 \%$ & $31.5 \%$ & $31.2 \%$ & $30.5 \%$ & $28.9 \%$ & $28.0 \%$ \\
\hline Libya & & & & & & $0.0 \%$ & $0.0 \%$ & \\
\hline Morocco & $18.6 \%$ & $19.3 \%$ & $19.5 \%$ & $19.8 \%$ & $20.4 \%$ & $16.9 \%$ & $17.3 \%$ & $16.4 \%$ \\
\hline Oman & $0.0 \%$ & $0.0 \%$ & $0.0 \%$ & $0.0 \%$ & $0.0 \%$ & $0.0 \%$ & $8.0 \%$ & $8.7 \%$ \\
\hline Tunisia & $10.8 \%$ & $11.0 \%$ & $11.5 \%$ & $11.7 \%$ & $11.9 \%$ & $12.1 \%$ & $14.9 \%$ & $14.8 \%$ \\
\hline Yemen, Rep. & $7.3 \%$ & $7.8 \%$ & $8.2 \%$ & $8.0 \%$ & $7.3 \%$ & $5.0 \%$ & $2.0 \%$ & $2.4 \%$ \\
\hline South Asia & $8.6 \%$ & $9.4 \%$ & $9.7 \%$ & $9.3 \%$ & $9.4 \%$ & $12.0 \%$ & $10.9 \%$ & $10.4 \%$ \\
\hline Bangladesh & $0.0 \%$ & $0.0 \%$ & $0.0 \%$ & $0.0 \%$ & $0.0 \%$ & $0.0 \%$ & $0.0 \%$ & $0.0 \%$ \\
\hline India & $0.9 \%$ & $1.1 \%$ & $1.3 \%$ & $1.3 \%$ & $1.3 \%$ & $1.7 \%$ & $1.4 \%$ & $0.5 \%$ \\
\hline Nepal & $38.9 \%$ & $41.7 \%$ & $42.0 \%$ & $39.4 \%$ & $40.0 \%$ & $52.8 \%$ & $46.7 \%$ & $45.4 \%$ \\
\hline Pakistan & $1.4 \%$ & $1.5 \%$ & $2.3 \%$ & $2.4 \%$ & $2.4 \%$ & $3.4 \%$ & $4.3 \%$ & $6.0 \%$ \\
\hline Sri Lanka & $2.2 \%$ & $2.5 \%$ & $3.1 \%$ & $3.2 \%$ & $3.3 \%$ & $2.3 \%$ & $2.4 \%$ & $0.3 \%$ \\
\hline Sub-Saharan Africa & $30.2 \%$ & $28.7 \%$ & $32.4 \%$ & $33.1 \%$ & $37.4 \%$ & $45.3 \%$ & $45.3 \%$ & $45.0 \%$ \\
\hline Angola & & & & & & & $38.1 \%$ & $43.0 \%$ \\
\hline Benin & & $49.4 \%$ & $48.2 \%$ & $46.0 \%$ & $46.0 \%$ & & $51.8 \%$ & $53.1 \%$ \\
\hline Botswana & $79.6 \%$ & $79.5 \%$ & $79.7 \%$ & $80.7 \%$ & $83.0 \%$ & $84.2 \%$ & $84.7 \%$ & $84.0 \%$ \\
\hline Burkina Faso & & & & $44.4 \%$ & $43.8 \%$ & $24.4 \%$ & $29.4 \%$ & $30.4 \%$ \\
\hline Burundi & $39.2 \%$ & $37.3 \%$ & $37.6 \%$ & $37.2 \%$ & $36.4 \%$ & $16.2 \%$ & $23.6 \%$ & $21.5 \%$ \\
\hline Cameroon & & & $65.4 \%$ & $64.0 \%$ & $63.9 \%$ & $54.9 \%$ & $56.7 \%$ & $59.0 \%$ \\
\hline Cote d'Ivoire & $20.3 \%$ & $19.7 \%$ & $20.0 \%$ & $23.8 \%$ & $53.6 \%$ & $58.3 \%$ & $62.8 \%$ & $61.8 \%$ \\
\hline Ethiopia & $0.0 \%$ & $0.0 \%$ & $0.0 \%$ & $0.0 \%$ & $0.0 \%$ & $0.0 \%$ & $0.0 \%$ & $0.0 \%$ \\
\hline Ghana & $28.4 \%$ & $29.9 \%$ & $53.8 \%$ & $53.9 \%$ & $57.6 \%$ & $64.7 \%$ & $52.1 \%$ & $52.8 \%$ \\
\hline Kenya & $26.6 \%$ & $27.6 \%$ & $27.6 \%$ & $29.4 \%$ & $28.6 \%$ & $31.6 \%$ & $34.4 \%$ & $36.0 \%$ \\
\hline Lesotho & & & & & & $84.9 \%$ & $86.1 \%$ & $86.3 \%$ \\
\hline Madagascar & $42.3 \%$ & & & & $63.3 \%$ & $62.1 \%$ & $61.4 \%$ & $62.0 \%$ \\
\hline Malawi & & $8.9 \%$ & $8.2 \%$ & $8.1 \%$ & $8.9 \%$ & $33.7 \%$ & $27.5 \%$ & $27.9 \%$ \\
\hline Mali & $41.1 \%$ & $41.3 \%$ & $40.6 \%$ & $40.3 \%$ & $40.8 \%$ & $57.6 \%$ & $49.9 \%$ & $48.9 \%$ \\
\hline Mauritius & $9.5 \%$ & $19.7 \%$ & $22.5 \%$ & $32.8 \%$ & $42.4 \%$ & $24.6 \%$ & $25.3 \%$ & $24.7 \%$ \\
\hline Mozambique & & $22.0 \%$ & $38.4 \%$ & $40.6 \%$ & $44.8 \%$ & $60.0 \%$ & $72.2 \%$ & $72.5 \%$ \\
\hline Namibia & $45.2 \%$ & $42.6 \%$ & $35.5 \%$ & $33.8 \%$ & $35.3 \%$ & $47.4 \%$ & $68.6 \%$ & $66.9 \%$ \\
\hline Niger & & & & & & $51.0 \%$ & $51.1 \%$ & $43.7 \%$ \\
\hline Nigeria & $10.1 \%$ & $10.1 \%$ & $10.1 \%$ & $9.5 \%$ & $12.5 \%$ & $15.0 \%$ & $10.5 \%$ & $11.2 \%$ \\
\hline Rwanda & & $22.4 \%$ & $22.8 \%$ & $21.1 \%$ & $23.7 \%$ & & & \\
\hline Senegal & & $43.1 \%$ & $42.5 \%$ & $42.6 \%$ & $42.8 \%$ & $42.3 \%$ & $40.9 \%$ & $39.1 \%$ \\
\hline Seychelles & & $12.6 \%$ & $13.1 \%$ & $13.6 \%$ & $13.8 \%$ & & & \\
\hline Sierra Leone & & & $0.0 \%$ & $0.0 \%$ & $0.0 \%$ & $31.6 \%$ & $32.2 \%$ & $29.5 \%$ \\
\hline South Africa & $0.3 \%$ & $0.2 \%$ & $0.2 \%$ & $0.2 \%$ & $0.2 \%$ & $11.4 \%$ & $10.4 \%$ & $10.8 \%$ \\
\hline Sudan & $0.0 \%$ & $0.0 \%$ & $0.0 \%$ & $0.0 \%$ & $0.0 \%$ & $3.0 \%$ & $2.9 \%$ & $4.7 \%$ \\
\hline Swaziland & & & & & & $79.1 \%$ & $74.7 \%$ & $71.1 \%$ \\
\hline Tanzania & & $26.0 \%$ & $31.5 \%$ & $31.5 \%$ & $34.6 \%$ & $63.5 \%$ & $64.3 \%$ & $64.3 \%$ \\
\hline Uganda & $39.7 \%$ & $38.5 \%$ & $36.3 \%$ & $69.8 \%$ & $76.0 \%$ & $53.8 \%$ & $53.9 \%$ & $55.4 \%$ \\
\hline Zambia & $55.2 \%$ & $52.9 \%$ & $93.6 \%$ & $57.2 \%$ & $61.1 \%$ & $69.7 \%$ & $68.4 \%$ & $66.6 \%$ \\
\hline Zimbabwe & $45.8 \%$ & $46.9 \%$ & $49.8 \%$ & $47.3 \%$ & $58.2 \%$ & $51.5 \%$ & $33.8 \%$ & $33.3 \%$ \\
\hline
\end{tabular}

Data source: Micco, Panizza, and Yañez (2006) 
Table 2: Banking Crises and Costs

\begin{tabular}{|c|c|c|}
\hline Country & Crisis Period & $\begin{array}{c}\text { Cost of the Crisis } \\
\text { (\% GDP) }\end{array}$ \\
\hline \multicolumn{3}{|l|}{ East Asia \& Pacific } \\
\hline China & 1990-1999 & \\
\hline Indonesia & $1992-1995$ & $2.0 \%$ \\
\hline Indonesia & $1997-2003$ & $55.0 \%$ \\
\hline Korea, Rep & $1997-2002$ & $28.0 \%$ \\
\hline Laos & 1997 & $1.5 \%$ \\
\hline Malaysia & $1997-2003$ & $16.4 \%$ \\
\hline Myanmar & 1996-1997 & \\
\hline Philippines & $1997-2002$ & $7.0 \%$ \\
\hline Thailand & $1997-2002$ & $34.8 \%$ \\
\hline Vietnam & $1997-2002$ & \\
\hline \multicolumn{3}{|c|}{ Eastern Europe \& Central Asia } \\
\hline Albania & 1992-1996 & \\
\hline Armenia & 1994-1996 & \\
\hline Azerbaijan & 1995 & \\
\hline Belarus & 1995 & \\
\hline Bosnia and Herzegovina & $1992-2003$ & \\
\hline Bulgaria & $1995-1997$ & $13.0 \%$ \\
\hline Croatia & 1996 & \\
\hline Czech Republic & $1991-1995$ & $12.0 \%$ \\
\hline Estonia & $1992-1995$ & $1.4 \%$ \\
\hline Georgia & 1991-1996 & \\
\hline Hungary & 1991-1995 & $10.0 \%$ \\
\hline Kyrgyz Republic & 1990-1999 & \\
\hline Latvia* & $1995-2003$ & $10.0 \%$ \\
\hline Lithuania & $1995-1996$ & \\
\hline Poland & 1990-1999 & $2.0 \%$ \\
\hline Romania & $1990-2003$ & \\
\hline Russian Federation & 1995 & \\
\hline Russian Federation & 1998-1999 & $5 \%-7 \%$ \\
\hline Slovak Republic & $1991-2003$ & $15.0 \%$ \\
\hline Tajikistan & 1996 & \\
\hline Turkey & 1991 & \\
\hline Turkey & 1994-1995 & $1.0 \%$ \\
\hline Turkey & $2000-2003$ & $30.5 \%$ \\
\hline Ukraine & $1997-1998$ & \\
\hline
\end{tabular}


Table 2: Banking Crises and Costs

\begin{tabular}{|c|c|c|}
\hline Country & Crisis Period & $\begin{array}{c}\text { Cost of the Crisis } \\
\text { (\% GDP) }\end{array}$ \\
\hline \multicolumn{3}{|c|}{ Latin America \& Caribbean } \\
\hline Argentina & 1995-1997 & $2.0 \%$ \\
\hline Argentina & $2000-2003$ & $2.0 \%$ \\
\hline Bolivia & 2001-2002 & \\
\hline Bolivia & 1994-1997 & \\
\hline Brazil & 1990 & \\
\hline Brazil & 1994-1999 & $13.2 \%$ \\
\hline Colombia & $1999-2000$ & $5.0 \%$ \\
\hline Costa Rica & 1994-1997 & \\
\hline Ecuador & $1995-2003$ & $20.0 \%$ \\
\hline Guyana & 1993-1995 & \\
\hline Jamaica & $1994-2000$ & $44.0 \%$ \\
\hline Mexico & 1994-1997 & $19.3 \%$ \\
\hline Nicaragua & 1985-1996 & \\
\hline Paraguay & 1995-1999 & $13.0 \%$ \\
\hline Uruguay & $2002-2003$ & $3.0 \%$ \\
\hline Venezuela, RB & 1993-1997 & $18 \% *$ \\
\hline \multicolumn{3}{|c|}{ Middle East \& North Africa } \\
\hline Egypt, Arab Rep. & $1991-1995$ & $0.5 \%$ \\
\hline Tunisia & 1991-1996 & \\
\hline Yemen, Rep. & 1996 & \\
\hline \multicolumn{3}{|l|}{ South Asia } \\
\hline Bangladesh & 1985-1996 & \\
\hline India & 1991-1997 & \\
\hline \multicolumn{3}{|l|}{ Sub-Saharan Africa } \\
\hline Angola & 1991-2003 & \\
\hline Botswana & 1994-1995 & \\
\hline Burundi & 1994-1997 & \\
\hline Cameroon & 1995-1998 & \\
\hline Cape Verde & 1993-1996 & \\
\hline Central African Republic & 1976-1999 & \\
\hline Congo, Rep. & $1992-2003$ & \\
\hline Ethiopia & 1994-1995 & \\
\hline Gabon & 1995 & \\
\hline Ghana & $1997-2002$ & $6 \% * *$ \\
\hline Guinea-Bissau & 1994-1997 & \\
\hline Kenya & $1992-1997$ & \\
\hline Mauritius & 1996 & \\
\hline Mozambique & $1987-1997$ & \\
\hline Nigeria & 1990-1999 & \\
\hline Sierra Leone & $1990-2003$ & \\
\hline Swaziland & 1995 & \\
\hline Tanzania & $1985-1999$ & \\
\hline Togo & $1993-1995$ & \\
\hline Uganda & $1994-2003$ & \\
\hline Zambia & 1995 & $14.0 \%$ \\
\hline Zimbabwe & $1995-2003$ & \\
\hline
\end{tabular}




\section{Table 3: Average Budget to GDP Before and After Crises}

\begin{tabular}{|l|c|c|}
\hline \multicolumn{1}{|c|}{ Region } & $\begin{array}{c}\text { Average Budget Deficit to } \\
\text { GDP 3 years before }\end{array}$ & $\begin{array}{c}\text { Average Budget Deficit to } \\
\text { GDP 3 years after }\end{array}$ \\
\hline East Asia \& Pacific & $0.20 \%$ & $-1.24 \%$ \\
Eastern Europe \& Central Asia & $-3.94 \%$ & $-4.18 \%$ \\
Latin America \& Caribbean & $-3.94 \%$ & $-3.17 \%$ \\
Middle East \& North Africa & $-7.08 \%$ & $-2.34 \%$ \\
South Asia & $-7.55 \%$ & $-5.95 \%$ \\
Sub-Saharan Africa & $-2.88 \%$ & $-3.64 \%$ \\
\hline
\end{tabular}

Source: World Development Indicators (World Bank) and International Financial Statistics (IMF) 
Table 4: Banking Sector Restrictions Across Crises and Non-crises Countries

\begin{tabular}{|l|c|}
\hline \multicolumn{1}{|c|}{ Country } & Banking restrictions* \\
\hline East Asia \& Pacific & 3.5 \\
Crises countries & 3.21 \\
Non-crises countries & \\
Eastern Europe \& Central Asia & 3.02 \\
Crises countries & 3.56 \\
Non-crises countries & \\
Latin America \& Caribbean & 2.72 \\
Crises countries & 2.79 \\
Non-crises countries & \\
Middle East \& North Africa & 3.25 \\
Crises countries & 3.47 \\
Non-crises countries & \\
South Asia & 3.81 \\
Crises countries & 2.88 \\
Non-crises countries & \\
Sub-Saharan Africa & 3.18 \\
Crises countries & 3.6 \\
Non-crises countries & \\
\hline
\end{tabular}

* Index developed by the Heritage Foundation with values from 1 to 5 where higher values indicate greater restrictions. 
Table 5

Cross-Country Regressions for the Percentage Change in Foreign Bank Participation

1995 to 2002

\begin{tabular}{|c|c|c|c|c|c|c|c|c|}
\hline Explanatory Variables & 1 & 2 & 3 & 4 & 5 & 6 & 7 & 8 \\
\hline \multirow[t]{2}{*}{ Banking Crisis } & 0.1126 & 0.1114 & 0.1000 & 0.0745 & 0.1045 & 0.1168 & 0.0921 & 0.0777 \\
\hline & {$[2.24]^{* *}$} & {$[2.16]^{* *}$} & {$[2.02]^{* *}$} & {$[1.58]$} & {$[2.31]^{* *}$} & {$[2.30]^{* *}$} & {$[2.16]^{* *}$} & {$[1.70]^{*}$} \\
\hline \multirow[t]{2}{*}{ Inflation } & 0.0006 & 0.0006 & -0.0007 & -0.0008 & 0.0004 & 0.0004 & -0.0009 & -0.0009 \\
\hline & {$[1.12]$} & {$[1.09]$} & {$[1.14]$} & {$[1.18]$} & {$[0.78]$} & {$[0.68]$} & {$[1.30]$} & {$[1.28]$} \\
\hline \multirow[t]{2}{*}{ GDP Growth } & 0.0109 & 0.0109 & 0.0122 & 0.0123 & 0.0086 & 0.0088 & 0.0108 & 0.0111 \\
\hline & {$[2.57]^{* *}$} & {$[2.45]^{* *}$} & {$[2.88]^{* * *}$} & {$[2.83]^{* * *}$} & {$[1.78]^{*}$} & {$[1.82]^{*}$} & {$[2.34]^{* *}$} & {$[2.42]^{* *}$} \\
\hline \multirow[t]{2}{*}{ Banking Index } & -0.0571 & -0.0574 & 0.0059 & 0.0075 & -0.0760 & -0.0789 & -0.0208 & -0.0156 \\
\hline & {$[1.27]$} & {$[1.26]$} & {$[0.15]$} & {$[0.21]$} & {$[1.63]$} & {$[1.68]^{*}$} & {$[0.50]$} & {$[0.38]$} \\
\hline \multirow[t]{2}{*}{ Property Rights } & 0.0215 & 0.0224 & -0.0212 & -0.0092 & 0.0208 & 0.0136 & -0.0185 & -0.0113 \\
\hline & {$[0.61]$} & {$[0.61]$} & {$[0.66]$} & {$[0.30]$} & {$[0.59]$} & {$[0.39]$} & {$[0.60]$} & {$[0.38]$} \\
\hline \multirow[t]{2}{*}{ Log average GDP 95-02 (Constant GDP) } & & 0.0006 & & 0.0274 & & -0.0160 & & 0.0156 \\
\hline & & {$[0.04]$} & & {$[1.48]$} & & {$[0.98]$} & & {$[0.94]$} \\
\hline \multirow[t]{2}{*}{ Base Foreign Owned Bank Share (95-96) } & & & & & -0.2398 & -0.2959 & -0.2722 & -0.2298 \\
\hline & & & & & {$[1.64]$} & {$[1.83]^{*}$} & {$[1.86]^{*}$} & {$[1.62]$} \\
\hline \multirow[t]{2}{*}{ Dummy (East Asia\& Pacific) } & & & -0.2699 & -0.3393 & & & -0.3050 & -0.3386 \\
\hline & & & {$[2.81]^{* * *}$} & {$[2.93]^{* * *}$} & & & {$[3.50]^{* * *}$} & {$[3.41]^{* * *}$} \\
\hline \multirow[t]{2}{*}{ Dummy (Europe and Central Asia) } & & & 0.1263 & 0.1008 & & & 0.0755 & 0.0691 \\
\hline & & & {$[1.93]^{*}$} & {$[1.44]$} & & & {$[1.02]$} & {$[0.92]$} \\
\hline \multirow[t]{2}{*}{ Dummy (Latin America \& Caribbean) } & & & 0.0199 & -0.0128 & & & -0.0277 & -0.0372 \\
\hline & & & {$[0.31]$} & {$[0.20]$} & & & {$[0.38]$} & {$[0.51]$} \\
\hline \multirow[t]{2}{*}{ Dummy (Middle East and North Africa) } & & & -0.1174 & -0.1513 & & & -0.1741 & -0.1848 \\
\hline & & & {$[2.26]^{* *}$} & {$[2.83]^{* * *}$} & & & {$[3.04]^{* * *}$} & {$[3.13]^{* * *}$} \\
\hline \multirow[t]{2}{*}{ Dummy (South Asia) } & & & -0.1089 & -0.1723 & & & -0.1649 & -0.1927 \\
\hline & & & {$[1.79]^{*}$} & {$[2.22]^{* *}$} & & & {$[2.13]^{* *}$} & {$[2.20]^{* *}$} \\
\hline \multirow[t]{2}{*}{ Constant } & 0.1614 & 0.1464 & 0.1480 & -0.4926 & 0.2698 & 0.6823 & 0.3112 & -0.0801 \\
\hline & {$[1.61]$} & {$[0.39]$} & {$[1.52]$} & {$[1.11]$} & {$[2.21]^{* *}$} & {$[1.57]$} & {$[2.51]^{* *}$} & {$[0.20]$} \\
\hline Observations & 78 & 77 & 78 & 77 & 78 & 77 & 78 & 77 \\
\hline R-squared & 0.13 & 0.12 & 0.36 & 0.39 & 0.17 & 0.18 & 0.41 & 0.42 \\
\hline
\end{tabular}

Robust t statistics in brackets, ${ }^{*}, * *$ and ${ }^{* * *}$ denote significance at 10,5 and 1 percent. 
Table 6

Regressions with Country Fixed Effects for the Share of Banking Sector Assets Held by Foreign Banks

\begin{tabular}{|c|c|c|c|c|c|c|c|c|}
\hline Explanatory Variables & 1 & 2 & 3 & 4 & 5 & 6 & 7 & 8 \\
\hline \multirow[t]{2}{*}{ Banking Cris is } & -0.067 & -0.058 & -0.024 & -0.022 & 0.059 & 0.018 & 0.000 & -0.035 \\
\hline & {$[4.41]^{* * *}$} & {$[4.63]^{* * *}$} & {$[1.80]^{*}$} & {$[1.85]^{*}$} & {$[1.90]^{*}$} & {$[0.74]$} & {$[0.01]$} & {$[1.52]$} \\
\hline \multirow[t]{2}{*}{ Post-Cris is } & & & & & 0.094 & 0.075 & 0.032 & 0.019 \\
\hline & & & & & {$[6.85]^{* * *}$} & {$[5.73]^{* * *}$} & {$[2.41]^{* *}$} & {$[1.43]$} \\
\hline \multirow[t]{2}{*}{ Inflation } & & -0.024 & & -0.043 & & -0.002 & & -0.001 \\
\hline & & {$[1.76]^{*}$} & & {$[3.38] * * *$} & & {$[4.85]^{* * *}$} & & {$[3.32] * * *$} \\
\hline \multirow[t]{2}{*}{ GDP Growth } & & 0.014 & & -0.034 & & -0.003 & & -0.001 \\
\hline & & {$[1.26]$} & & {$[2.97]^{* * *}$} & & {$[1.87]^{*}$} & & {$[0.80]$} \\
\hline \multirow[t]{2}{*}{ Banking Index } & & -0.002 & & -0.001 & & -0.025 & & -0.042 \\
\hline & & {$[5.11]^{* * *}$} & & {$[3.22]^{* * *}$} & & {$[1.86]^{*}$} & & {$[3.34] * * *$} \\
\hline \multirow[t]{2}{*}{ Property Rights } & & -0.003 & & -0.001 & & 0.011 & & -0.034 \\
\hline & & {$[2.06]^{* *}$} & & {$[0.60]$} & & {$[1.04]$} & & {$[3.01]^{* * *}$} \\
\hline \multirow[t]{2}{*}{ Dummy 1996} & & & 0.001 & -0.008 & & & -0.001 & -0.007 \\
\hline & & & {$[0.09]$} & {$[0.51]$} & & & {$[0.08]$} & {$[0.45]$} \\
\hline \multirow[t]{2}{*}{ Dummy 1997} & & & 0.029 & 0.019 & & & 0.024 & 0.022 \\
\hline & & & {$[2.03]^{* *}$} & {$[1.22]$} & & & {$[1.57]$} & {$[1.35]$} \\
\hline \multirow[t]{2}{*}{ Dummy 1998} & & & 0.043 & 0.027 & & & 0.037 & 0.029 \\
\hline & & & {$[3.12]^{* * *}$} & {$[1.66]^{*}$} & & & {$[2.50]^{* *}$} & {$[1.78]^{*}$} \\
\hline \multirow[t]{2}{*}{ Dummy 1999} & & & 0.059 & 0.045 & & & 0.053 & 0.048 \\
\hline & & & {$[4.38]^{* * *}$} & {$[2.88]^{* * *}$} & & & {$[3.59]^{* * *}$} & {$[2.99] * * *$} \\
\hline \multirow{2}{*}{ Dummy 2000} & & & 0.107 & 0.104 & & & 0.1 & 0.104 \\
\hline & & & {$[7.34]^{* * *}$} & {$[6.38]^{* * *}$} & & & {$[6.24]^{* * *}$} & {$[5.98]^{* * *}$} \\
\hline \multirow[t]{2}{*}{ Dummy 2001} & & & 0.12 & 0.12 & & & 0.113 & 0.123 \\
\hline & & & {$[7.77] * * *$} & {$[6.79] * * *$} & & & {$[6.70]^{* * *}$} & {$[6.61]^{* * *}$} \\
\hline \multirow[t]{2}{*}{ Dummy 2002} & & & 0.134 & 0.134 & & & 0.126 & 0.135 \\
\hline & & & {$[7.67]^{* * *}$} & {$[7.05]^{* * *}$} & & & {$[7.35]^{* * *}$} & {$[6.84]^{* * *}$} \\
\hline \multirow[t]{2}{*}{ Constant } & 0.274 & 0.338 & 0.197 & 0.451 & 0.193 & 0.292 & 0.185 & 0.455 \\
\hline & {$[46.13]^{* * *}$} & {$[6.99]^{* * *}$} & {$[16.45]^{* * *}$} & {$[8.61]^{* * *}$} & {$[10.62] * * *$} & {$[5.97]^{* * *}$} & {$[10.28]^{* * *}$} & {$[8.32]^{* * *}$} \\
\hline Observations & 713 & 640 & 713 & 640 & 713 & 647 & 713 & 647 \\
\hline Number of countries & 102 & 99 & 102 & 99 & 102 & 99 & 102 & 99 \\
\hline R-squared & 0.04 & 0.13 & 0.25 & 0.32 & 0.09 & 0.14 & 0.25 & 0.31 \\
\hline
\end{tabular}

Robust $t$ statistics in brackets, ${ }^{*}, * *$ and $* * *$ denote significance at 10,5 and 1 percent. 
Table 7

Regressions with Country Fixed Effects:

Dependent Variable, Credit to the Private Sector/GDP

\begin{tabular}{|c|c|c|c|c|c|c|c|c|}
\hline Explanatory Variables & 1 & 2 & 3 & 4 & 5 & 6 & 7 & 8 \\
\hline Banking Cris is & & & & & $\begin{array}{c}0.048 \\
{[1.77]^{*}}\end{array}$ & $\begin{array}{l}0.045 \\
{[1.64]}\end{array}$ & $\begin{array}{c}0.045 \\
{[1.69]^{*}}\end{array}$ & $\begin{array}{l}0.043 \\
{[1.56]}\end{array}$ \\
\hline Post-Cris is & $\begin{array}{c}0.046 \\
{[3.56]^{* * *}}\end{array}$ & $\begin{array}{c}0.047 \\
{[3.35]^{* * *}}\end{array}$ & $\begin{array}{c}0.038 \\
{[2.97]^{* * *}}\end{array}$ & $\begin{array}{c}0.040 \\
{[2.92]^{* * *}}\end{array}$ & $\begin{array}{c}0.043 \\
{[3.18]^{* * *}}\end{array}$ & $\begin{array}{c}0.045 \\
{[3.10]^{* * *}}\end{array}$ & $\begin{array}{c}0.037 \\
{[2.85]^{* * *}}\end{array}$ & $\begin{array}{c}0.039 \\
{[2.82]^{* * *}}\end{array}$ \\
\hline FOB Share & $\begin{array}{c}0.086 \\
{[2.49]^{* *}}\end{array}$ & $\begin{array}{c}0.069 \\
{[2.02]^{* *}}\end{array}$ & $\begin{array}{c}0.127 \\
{[3.35]^{* * *}}\end{array}$ & $\begin{array}{c}0.122 \\
{[3.03]^{* * *}}\end{array}$ & $\begin{array}{c}0.064 \\
{[1.82]^{*}}\end{array}$ & $\begin{array}{c}0.056 \\
{[1.59]}\end{array}$ & $\begin{array}{c}0.121 \\
{[3.13]^{* * *}}\end{array}$ & $\begin{array}{c}0.117 \\
{[2.88]^{* * *}}\end{array}$ \\
\hline FOB $\times$ Post-Cris is & $\begin{array}{c}-0.094 \\
{[2.79]^{* * *}}\end{array}$ & $\begin{array}{c}-0.094 \\
{[2.74]^{* * *}}\end{array}$ & $\begin{array}{c}-0.208 \\
{[3.82]^{* * *}}\end{array}$ & $\begin{array}{c}-0.214 \\
{[3.83]^{* * *}}\end{array}$ & $\begin{array}{c}-0.084 \\
{[2.49]^{* *}}\end{array}$ & $\begin{array}{c}-0.085 \\
{[2.46]^{* *}}\end{array}$ & $\begin{array}{c}-0.202 \\
{[3.68]^{* * *}}\end{array}$ & $\begin{array}{c}-0.208 \\
{[3.69]^{* * *}}\end{array}$ \\
\hline In itial FOB $x$ Post-Cris is & & & $\begin{array}{c}0.202 \\
{[3.62]^{* * *}}\end{array}$ & $\begin{array}{c}0.209 \\
{[3.68]^{* * *}}\end{array}$ & & & $\begin{array}{c}0.198 \\
{[3.53]^{* * *}}\end{array}$ & $\begin{array}{c}0.205 \\
{[3.59]^{* * *}}\end{array}$ \\
\hline Inflation & $\begin{array}{l}0.000 \\
{[0.23]}\end{array}$ & $\begin{array}{l}0.000 \\
{[0.32]}\end{array}$ & $\begin{array}{c}0.000 \\
{[0.91]}\end{array}$ & $\begin{array}{c}0.000 \\
{[0.40]}\end{array}$ & $\begin{array}{l}0.000 \\
{[0.63]}\end{array}$ & $\begin{array}{l}0.000 \\
{[0.14]}\end{array}$ & $\begin{array}{c}0.000 \\
{[0.79]}\end{array}$ & $\begin{array}{c}0.000 \\
{[0.30]}\end{array}$ \\
\hline GDP growth & $\begin{array}{c}-0.003 \\
{[3.54]^{* * *}}\end{array}$ & $\begin{array}{c}-0.003 \\
{[3.22]^{* * *}}\end{array}$ & & & & & & \\
\hline Banking Index & $\begin{array}{c}0.003 \\
{[0.37]}\end{array}$ & $\begin{array}{c}0.002 \\
{[0.23]}\end{array}$ & $\begin{array}{l}0.002 \\
{[0.36]}\end{array}$ & $\begin{array}{l}0.002 \\
{[0.31]}\end{array}$ & $\begin{array}{l}0.002 \\
{[0.29]}\end{array}$ & $\begin{array}{l}0.002 \\
{[0.26]}\end{array}$ & $\begin{array}{l}0.002 \\
{[0.27]}\end{array}$ & $\begin{array}{l}0.002 \\
{[0.24]}\end{array}$ \\
\hline Property Rights & $\begin{array}{c}-0.016 \\
{[2.01]^{* *}}\end{array}$ & $\begin{array}{c}-0.016 \\
{[2.01]^{* *}}\end{array}$ & $\begin{array}{l}-0.014 \\
{[1.79]^{*}}\end{array}$ & $\begin{array}{c}-0.014 \\
{[1.76]^{*}}\end{array}$ & $\begin{array}{l}-0.015 \\
{[1.92]^{*}}\end{array}$ & $\begin{array}{l}-0.015 \\
{[1.87]^{*}}\end{array}$ & $\begin{array}{l}-0.015 \\
{[1.89]^{*}}\end{array}$ & $\begin{array}{c}-0.015 \\
{[1.85]^{*}}\end{array}$ \\
\hline Concentration & & $\begin{array}{c}-0.090 \\
{[2.41]^{* *}}\end{array}$ & & $\begin{array}{l}-0.063 \\
{[1.81]^{*}}\end{array}$ & & $\begin{array}{l}-0.059 \\
{[1.67]^{*}}\end{array}$ & & $\begin{array}{l}-0.058 \\
{[1.65]}\end{array}$ \\
\hline Constant & $\begin{array}{c}0.282 \\
{[9.39]^{* * *}} \\
\end{array}$ & $\begin{array}{c}0.352 \\
{[7.99]^{* * *}}\end{array}$ & $\begin{array}{c}0.267 \\
{[9.14]^{* * *}}\end{array}$ & $\begin{array}{c}0.313 \\
{[7.34]^{* * *}}\end{array}$ & $\begin{array}{c}0.258 \\
{[7.65]^{* * *}}\end{array}$ & $\begin{array}{c}0.303 \\
{[6.49]^{* * *}}\end{array}$ & $\begin{array}{c}0.245 \\
{[7.38]^{* * *}} \\
\end{array}$ & $\begin{array}{c}0.288 \\
{[6.13]^{* * *}} \\
\end{array}$ \\
\hline Observations & 559 & 541 & 554 & 536 & 554 & 536 & 554 & 536 \\
\hline Number of countries & 79 & 79 & 79 & 79 & 79 & 79 & 79 & 79 \\
\hline R-squared & 0.09 & 0.1 & 0.1 & 0.11 & 0.09 & 0.09 & 0.11 & 0.12 \\
\hline
\end{tabular}

Robust t statistics in brackets, ${ }^{*}, * *$ and $* * *$ denote significance at 10,5 and 1 percent 
Table 8

Split-Sample Tests, Regressions with Country Fixed Effects

Dependent Variable, Credit to the Private Sector/GDP

\begin{tabular}{|c|c|c|c|c|}
\hline \multirow[b]{2}{*}{ Explanatory Variables } & \multicolumn{2}{|c|}{$\begin{array}{c}\text { Sample } \\
\text { Initial } \mathrm{FOB}>=10 \%\end{array}$} & \multicolumn{2}{|c|}{$\begin{array}{c}\text { Sample } \\
\text { Initial } \mathrm{FOB}<10 \%\end{array}$} \\
\hline & 1 & 2 & 3 & 4 \\
\hline Banking Cris is & & $\begin{array}{l}-0.006 \\
{[0.35]}\end{array}$ & & $\begin{array}{c}0.054 \\
{[1.73]^{*}}\end{array}$ \\
\hline Post-Cris is & $\begin{array}{l}0.022 \\
{[0.85]}\end{array}$ & $\begin{array}{c}0.022 \\
{[0.84]}\end{array}$ & $\begin{array}{c}0.067 \\
{[3.84]^{* * *}}\end{array}$ & $\begin{array}{c}0.067 \\
{[3.85]^{* * *}}\end{array}$ \\
\hline FOB Share & $\begin{array}{c}0.12 \\
{[2.79]^{* * *}}\end{array}$ & $\begin{array}{c}0.121 \\
{[2.68]^{* * *}}\end{array}$ & $\begin{array}{c}0.102 \\
{[1.51]}\end{array}$ & $\begin{array}{c}0.098 \\
{[1.45]}\end{array}$ \\
\hline FOB $x$ Post-Cris is & $\begin{array}{c}-0.224 \\
{[3.16]^{* * *}}\end{array}$ & $\begin{array}{c}-0.225 \\
{[3.11]^{* * *}}\end{array}$ & $\begin{array}{l}-0.14 \\
{[1.55]}\end{array}$ & $\begin{array}{l}-0.126 \\
{[1.38]}\end{array}$ \\
\hline Initial FOB $x$ Post-Cris is & $\begin{array}{c}0.233 \\
{[3.27]^{* * *}}\end{array}$ & $\begin{array}{c}0.234 \\
{[3.23]^{* * *}}\end{array}$ & $\begin{array}{l}-0.663 \\
{[1.21]}\end{array}$ & $\begin{array}{l}-0.752 \\
{[1.30]}\end{array}$ \\
\hline Inflation & $\begin{array}{c}-0.001 \\
{[3.34]^{* * *}}\end{array}$ & $\begin{array}{c}-0.001 \\
{[3.28]^{* * *}}\end{array}$ & $\begin{array}{c}0 \\
{[0.83]}\end{array}$ & $\begin{array}{c}0 \\
{[0.83]}\end{array}$ \\
\hline GDP growth & $\begin{array}{l}-0.002 \\
{[1.25]}\end{array}$ & $\begin{array}{l}-0.002 \\
{[1.25]}\end{array}$ & $\begin{array}{c}-0.003 \\
{[2.82]^{* * *}}\end{array}$ & $\begin{array}{c}-0.003 \\
{[2.39]^{* *}}\end{array}$ \\
\hline Banking Index & $\begin{array}{c}-0.016 \\
{[2.18]^{* *}}\end{array}$ & $\begin{array}{c}-0.016 \\
{[2.18]^{* *}}\end{array}$ & $\begin{array}{c}0.022 \\
{[1.87]^{*}}\end{array}$ & $\begin{array}{c}0.022 \\
{[1.86]^{*}}\end{array}$ \\
\hline Property Rights & $\begin{array}{c}0.013 \\
{[1.17]}\end{array}$ & $\begin{array}{c}0.013 \\
{[1.17]}\end{array}$ & $\begin{array}{c}-0.03 \\
{[2.62]^{* * *}}\end{array}$ & $\begin{array}{c}-0.033 \\
{[2.73]^{* * *}}\end{array}$ \\
\hline Concentration & $\begin{array}{l}-0.067 \\
{[1.37]}\end{array}$ & $\begin{array}{l}-0.066 \\
{[1.36]}\end{array}$ & $\begin{array}{l}-0.053 \\
{[1.07]}\end{array}$ & $\begin{array}{l}-0.035 \\
{[0.69]}\end{array}$ \\
\hline Constant & $\begin{array}{c}0.271 \\
{[5.93] * * *}\end{array}$ & $\begin{array}{c}0.274 \\
{[6.04]^{* * *}}\end{array}$ & $\begin{array}{c}0.328 \\
{[4.82]^{* * *}}\end{array}$ & $\begin{array}{c}0.29 \\
{[3.96]^{* * *}}\end{array}$ \\
\hline $\begin{array}{l}\text { Observations } \\
\text { Number of countries } \\
\text { R-squared }\end{array}$ & $\begin{array}{c}285 \\
43 \\
0.2\end{array}$ & $\begin{array}{c}285 \\
43 \\
0.2\end{array}$ & $\begin{array}{c}251 \\
36 \\
0.13\end{array}$ & $\begin{array}{c}251 \\
36 \\
0.15\end{array}$ \\
\hline
\end{tabular}


Figure 1: Foreign Bank Participation Across Regions, 1995-2002

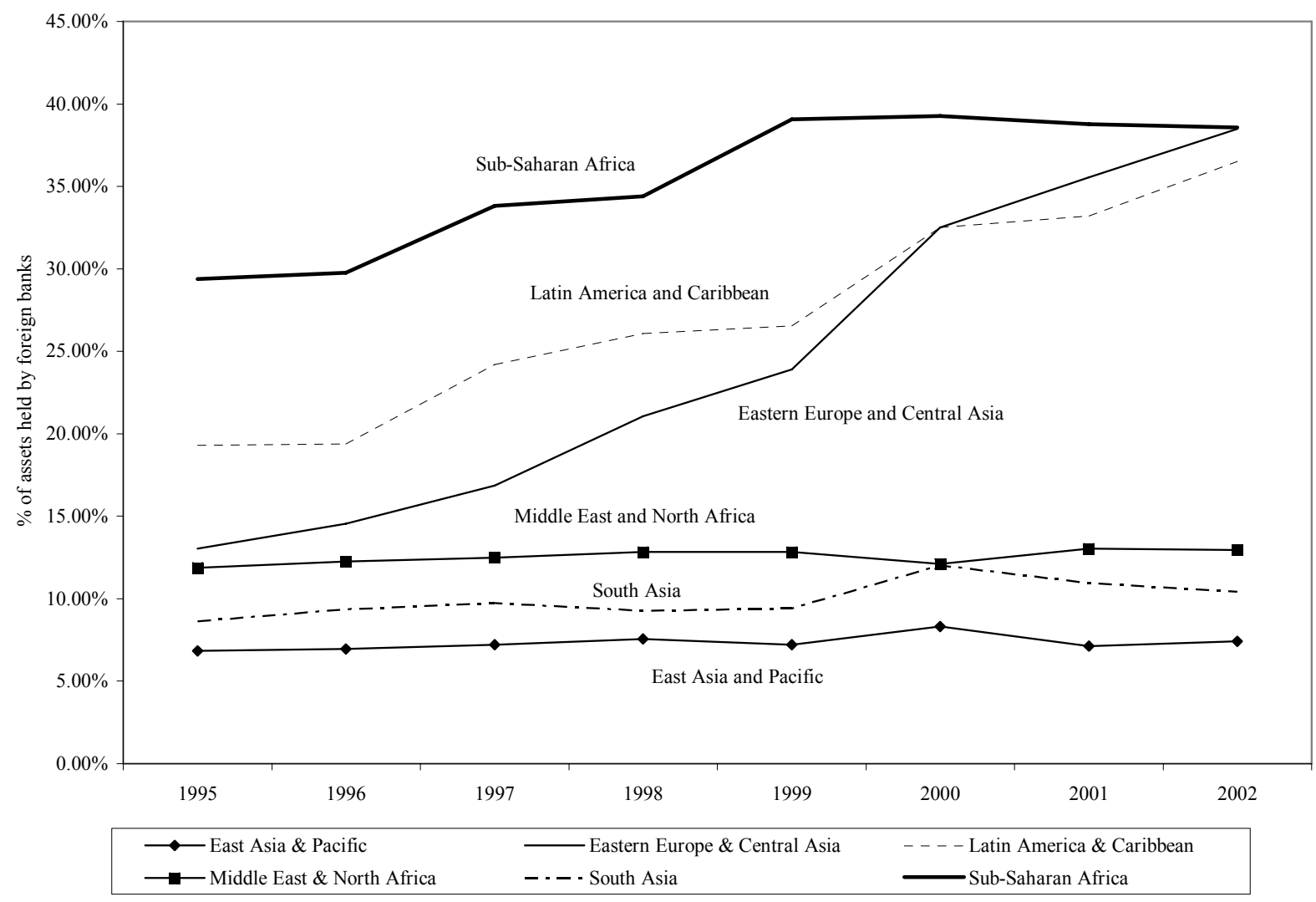

Data source: Micco, Panizza, and Yañez 
Figure 2: Foreign Bank Participation Across Regions Following Banking Crises

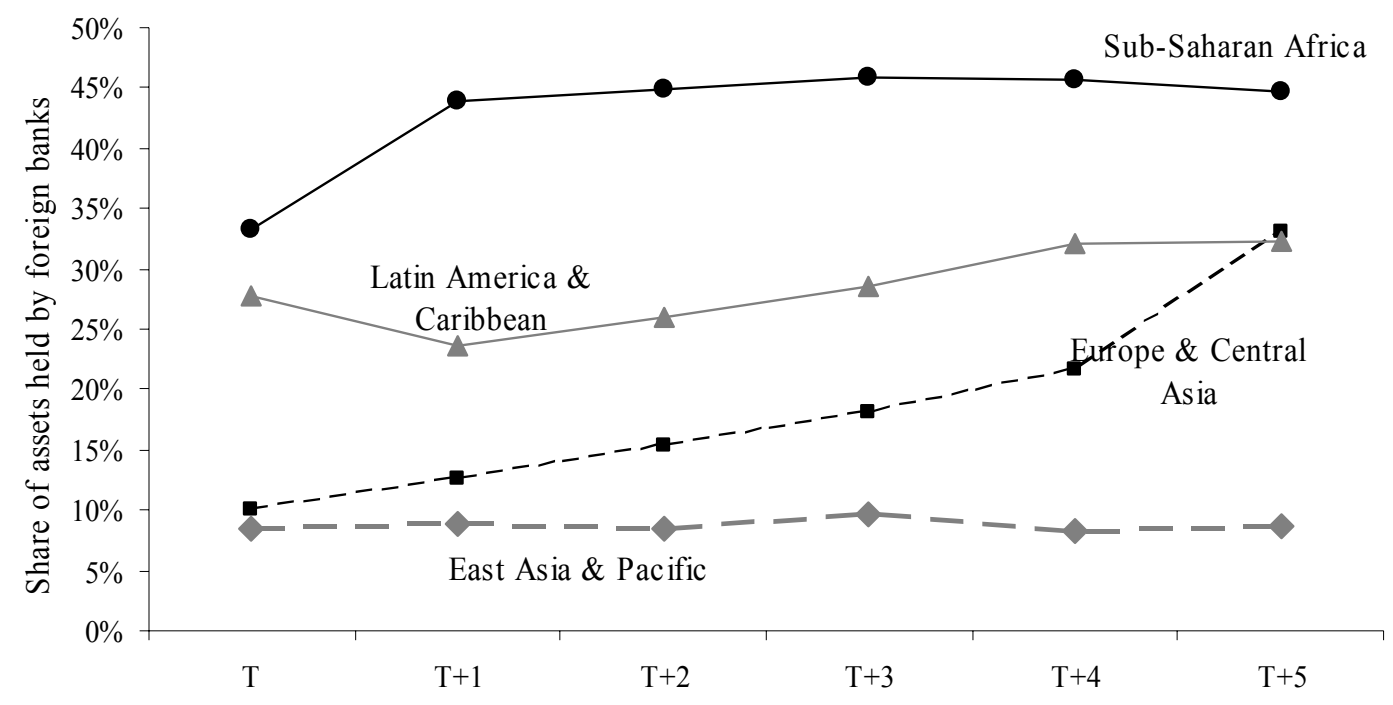

Data source: Micco, Panizza, and Yañez (2006) 